\title{
Credit Lines as Monitored Liquidity Insurance: Theory and Evidence*
}

\author{
Viral Acharya \\ New York University \\ CEPR \& NBER \\ vacharya@stern.nyu.edu
}

Filippo Ippolito

Universitat Pompeu Fabra

\& Barcelona GSE

filippo.ippolito@upf.edu

\author{
Heitor Almeida \\ University of Illinois \\ E $N B E R$ \\ halmeida@illinois.edu
}

\author{
Ander Perez \\ Universitat Pompeu Fabra \\ E Barcelona GSE \\ ander.perez@upf.edu
}

First draft: October 2011; This draft: November 2011

\begin{abstract}
Recent empirical and survey evidence on corporate liquidity management suggests that bank credit lines do not offer fully committed liquidity insurance, and that they are frequently used to finance future growth opportunities rather than for precautionary motives. In this paper, we propose and test a theory of corporate liquidity management that is consistent with these findings. We argue that a corporate credit line can be understood as a form of monitored liquidity insurance, which controls illiquidity-seeking behavior by firms through bank monitoring and credit line revocation. In addition, we allow firms to demand liquidity not to hedge against negative liquidity shocks, but to help finance future growth opportunities. We show that bank monitoring and credit line revocation play less of a role for such firms, because the nature of their liquidity demand reduces their incentives to engage in illiquidity-seeking behavior. Thus, firms that have low hedging-needs (e.g., high correlation between cash flows and investment opportunities) can access fully committed credit lines that dominate cash holdings as an optimal liquidity management tool. We use a novel dataset on corporate credit lines to provide empirical evidence that is consistent with the predictions of the model. The evidence suggests that credit line users have lower liquidity risk than firms that use cash for liquidity management. In addition, firms with low hedging-needs are more likely to use credit lines for liquidity management. Credit line covenants and covenant violations are less common when the credit line user has low hedging needs.
\end{abstract}

Key words: Liquidity management, cash holdings, liquidity risk, hedging, covenants, loan commitments, credit line revocation

JEL classification: G21, G31, G32, E22, E5.

*We are grateful to Ping Liu for excellent research assistance. 


\section{Introduction}

There is a growing empirical literature on the role of credit lines in corporate finance (Sufi (2009), Yun (2009), Acharya, Almeida and Campello (2009), Lins, Servaes, and Tufano (2010), Campello, Giambona, Graham, and Harvey (2010), and Disatnik, Duchin, and Schmidt (2010)). This recent empirical literature takes advantage of the growing availability of data to test some of the implications of earlier theories of credit lines (e.g., Holmstrom and Tirole (1997, 1998) and Shockley and Thakor (1997)). Yet, there seems to be a disconnect between these earlier theories and recent empirical findings.

Theory suggests that the main difference between a credit line and standard debt is that a credit line allows the firm to access pre-committed debt capacity. This pre-commitment creates value for credit lines as a corporate liquidity management tool, in that it helps insulate the corporation from negative shocks that may hinder access to capital markets. In particular, credit lines can be an effective, and likely cheaper substitute for corporate cash holdings as a liquidity management tool. Nevertheless, the results in Sufi (2009) challenge the notion that credit lines have perfect commitment. Access to credit lines is often restricted precisely when the firm needs it most, that is, following negative profitability shocks that cause contractual covenant violations. In addition, the survey evidence in Lins, Servaes and Tufano (2010) suggests that CFOs do not always use credit lines as precautionary savings, but rather to finance future growth opportunities. Finally, the large literature on corporate cash holdings shows that cash is a very prevalent liquidity management tool, and does not appear to be universally dominated by credit lines (e.g., Opler, Pinkowitz, Stulz, and Williamson (1999), Almeida, Campello, and Weisbach (2004), Duchin (2010), and Campello et al. (2010)).

In this paper, we propose and test a theory of corporate liquidity management that bridges the gap between theory and empirical evidence on credit lines. There are two key insights underlying our theory.

First, a corporate credit line can be understood as a form of monitored liquidity insurance. A fully committed credit line (that is, full and irrevocable liquidity insurance) may not be optimal because it induces illiquidity-seeking behavior by firms once the credit line has been contracted. In presence of such potential firm behavior, modeling the revocability of credit lines helps understand why covenants are present in credit line contracts in the first place. Specifically, the role of covenants is to facilitate monitored liquidity insurance, where the need

for bank monitoring of firms arises precisely due to the problem of illiquidity-seeking behavior by firms.

Second, some firms may demand liquidity not to withstand negative liquidity shocks, but 
to help fund future growth opportunities. As a result, demand for additional liquidity may arise in "good" future states of the world if firm's cash flows and investment opportunities are highly positively correlated. Such firms would also have a demand for bank credit lines as an efficient way to manage future liquidity needs, but this is from an investment motive rather than a precautionary savings motive.

In detail, bank monitoring arises as a solution to a tension that is natural in a liquidity insurance context. While liquidity insurance protects firms from value-destroying liquidity shocks, once such insurance is in place firms may gain incentives to engage in risky investments that increase the risk of liquidity shocks ("illiquidity transformation"). Bank-provided credit lines can help eliminate the incentive for illiquidity transformation, because the bank retains the right (through credit line covenants) to deny access to the credit line if it obtains a signal that the firm might have engaged in such transformation. Thus, bank monitoring and ensuing credit line revocation provides incentives for the firm to avoid illiquidity transformation.

However, credit lines do not always dominate cash holdings, despite the presence of a liquidity premium to be incurred while retaining cash. The cost of credit line-provided liquidity insurance arises from direct monitoring costs, and due to the equilibrium need to revoke credit lines of even those firms that face genuine liquidity shocks that do not arise from illiquidity transformation. In order to maintain the bank's incentives to monitor in equilibrium, the bank must be allowed to deny credit line access to a fraction of firms that face a liquidity shock, even if these firms did not engage in illiquidity transformation in the first place (otherwise the bank would not be willing to spend resources on monitoring). Such possibility of credit line revocation creates a cost of credit line-provided liquidity insurance. In equilibrium, firms may then choose to switch to cash holdings if the cost of credit lines is too high.

In particular, the model points out to an important determinant of the choice between cash and credit lines - the firm's total liquidity risk. Firms with greater liquidity risk must be monitored more often, causing direct and indirect monitoring costs (i.e., expected credit line revocation) to increase. Thus, firms with higher liquidity risk are particularly likely to forego monitored liquidity insurance and to switch to self-insurance (cash holdings).

In addition, we follow Froot, Scharfstein and Stein (1993) and Acharya, Almeida and Campello (2007) and extend the model to allow some firms to demand liquidity not to survive liquidity shocks in bad states of the world, but to pursue additional investment opportunities in good states of the world. Such a scenario is more likely when firms have "low hedging needs," or in other words a high correlation between availability of internal funds and investment opportunities. Such firms are unlikely to need liquidity in bad states of the world, as they also have poorer investment opportunities in such states. They may also not require liquidity 
in good states of the world if they have sufficient internal funds and standard debt capacity in those states. But in case they do require liquidity in good states, then they use credit lines since they can have access to fully committed credit lines. These firms use credit lines to help finance new investment opportunities that arise in good times, consistent with the survey evidence from Lins, Servaes and Tufano (2010). In addition, bank monitoring and credit line covenants play no role for such firms, because the demand for credit lines arises in good states of the world when these firms do not have incentives to engage in illiquidity transformation.

The model generates a number of empirical implications. Some of these implications help understand existing empirical results, while others are new to the literature on liquidity management. One of the model's insights is that firms switch to cash holdings to manage liquidity when the cost of monitored liquidity insurance through the credit line is too high. Because the cost of monitoring increases with the firm's liquidity risk, high risk firms move away from credit lines to cash. This insight helps understand some of the empirical results in Sufi (2009), who finds that firms with high cash flow risk and low cash flows are more likely to use cash for liquidity management. Sufi also finds that firms' available credit lines decrease when declines in performance cause firms to violate covenants. In our model, this pattern arises from an optimal liquidity management policy that discourages credit line users from engaging in illiquidity transformation.

Importantly, the revocation feature of credit line contracts is not incompatible with credit lines' role as liquidity insurance. In fact, the model also predicts that credit line drawdowns will also tend to happen following decreases in performance, as some firms will need to access their credit lines to meet liquidity needs. However, since firms that use credit lines in equilibrium (instead of switching to cash) have low liquidity risk, credit line drawdowns should be relatively infrequent when compared to usage of cash holdings to meet liquidity needs. We use our data on drawdowns to test both implications, which are new to the literature.

In addition, the model helps understand some of the other factors that appear to be correlated with the cash/credit line choice. For example, the results in Sufi (2009) show that $Q$ has a very robust, negative correlation with the ratio of credit lines to total liquidity. Our model shows that this implication also arises naturally from a framework in which a credit line is monitored liquidity insurance. Intuitively, the choice between the liquid and the illiquid projects is equivalent to a choice between pledgeability and productivity. The liquid project has greater pledgeability, and allows the firm to increase investment levels. Thus, the illiquid project will only be chosen in equilibrium when its payoff per unit of investment (or the productivity of investment) is larger than that of the liquid project. But due to the problem of illiquidity-seeking behavior by firms, liquid projects are financed using monitored liquidity 
insurance or bank credit lines, whereas illiquid projects are optimally financed using cash.

The other novel implications of the model for liquidity management come from the consideration of liquidity management for good times. A key result of the theory is that because firms with low hedging needs demand credit lines in good states of the world, these credit lines can be fully committed and do not require the bank to retain revocation rights through covenants. Thus, credit lines should dominate cash holdings for firms with low hedging needs (i.e., high correlation between cash flows and investment opportunities). In addition, these credit lines should be less likely to include covenants. And finally, low hedging needs firms should be less likely to violate covenants associated with credit lines.

Our empirical analysis extends the existing literature by considering these new implications and by introducing a new, large dataset that contains detailed information on credit lines. The credit line data come from Capital IQ (CIQ), and cover a large sample of firms for the period of 2002 to 2008. CIQ compiles detailed information on capital structure and debt structure by going through financial footnotes contained in firms' $10 \mathrm{~K}$ Securities and Exchange Commission (SEC) filings. Most importantly for our purposes, firms provide detailed information on the drawn and undrawn portions of their lines of credit in the liquidity and capital resources section under the management discussion, or in the financial footnotes explaining debt obligations, and CIQ compiles these data.

We find evidence that supports the empirical implications of the model and confirms earlier findings (as in Sufi, 2009). Consistent with existing empirical evidence that is based on alternative datasets, the Capital IQ data suggest that profitable, safer, low $Q$ and high tangibility firms are more likely to have credit lines and less likely to use cash for liquidity management. Credit line users also tend to have higher bond ratings, and are more likely to have a rating to begin with when compared to firms that use cash for liquidity management.

In addition, we show novel evidence that credit line drawdowns tend to occur following declines in profitability, suggesting that credit lines do provide liquidity insurance to firms. Still, we find that credit line drawdowns are relatively infrequent relative to cash reductions in situations in which firms are likely to have a liquidity need, which we define as a year in which profitability is negative. In particular, the likelihood of a credit line drawdown to fund a liquidity shock (among credit line users) is close to 10 times lower than the likelihood of a reduction in cash holdings to fund a similar liquidity shock among cash users. This evidence suggests that credit line users have lower liquidity risk, when compared to firms that use cash for liquidity management.

We also provide novel evidence linking corporate hedging needs to liquidity management and credit line contracting. Following existing literature (Acharya, Almeida and Campello 
(2007) and Duchin (2010)), we measure hedging needs by correlating firm cash flows with investment opportunities. We measure investment opportunities using two alternative industrylevel proxies, median industry annual investment activities and median industry Tobin's Q. In addition we collect information from LPC Dealscan on covenants attached to new credit lines issued to the firms in our sample and from Nini, Smith and Sufi (2010) on covenant violations. In line with the predictions of our model, we find that low-hedging needs firms (those with the highest correlations between cash flows and investment opportunities) are the most likely to use credit lines. Depending on the measure chosen, the low hedging-needs firms are between 8 and $26 \%$ more likely to have a line of credit than high hedging-needs firms. The credit lines of low hedging-needs firms are also less likely to contain covenants, and these covenants are less likely to be violated. These findings support the model's implication that credit lines are less costly for low-hedging needs firms, since they suffer from a lower illiquidity-seeking problem and the credit line provider (the bank) is less likely to retain revocation rights through covenants.

Overall, the evidence suggests that bank monitoring and cross-sectional variation in hedging needs have an important role to play in explaining the demand for credit lines and corporate liquidity management. Our results help bridge the gap between theory and existing empirical work on corporate credit lines, and contain new findings that link credit line usage and contracting features (such as the usage of covenants, their ex-post violation, and revocation of credit lines) to the specific type of liquidity management that is important for corporations (precautionary savings or the financing of future growth opportunities).

We start in the next section by introducing the benchmark model in which credit line revocation works as an incentive device for the firm to pre-commit to a liquid investment choice. The basic model assumes that firms demand liquidity for bad states of the world, to survive liquidity shocks. In Section 2.4 we extend the model to consider liquidity management for good times, and show that in this case credit lines become a fully committed liquidity management tool, and thus dominate cash holdings. Section 3 summarizes the empirical implications of the model. Section 4 introduces and presents our empirical analysis, and Section 5 concludes the paper.

\section{A model of credit line revocation as a monitoring mechanism}

In this section, we show how credit line revocation by banks can be modeled as an optimal monitoring mechanism when the firm may engage in illiquidity-seeking behavior after 
acquiring insurance through a credit line against its liquidity risk.

\subsection{Illiquidity transformation and bank monitoring}

The timing of the model is depicted in Figure 1. Each firm has access to an investment project that requires fixed investment $I$ at date 0 and an additional investment at date 1 , of uncertain size (the firm's liquidity need). The date-1 investment need can be either equal to $\rho$, with probability $\hat{\lambda}$, or 0 , with probability $(1-\hat{\lambda})$. The probability $\hat{\lambda}$ is endogenous. Specifically, $\widehat{\lambda}$ is either equal to $\lambda$, or equal to $\lambda^{\prime}>\lambda$. The manager chooses the probability $\widehat{\lambda}$ after the initial investment has been made. This probability is unobservable to outside parties at date-1, who can only observe whether or not the firm has an additional investment need (that is, $\rho$ is observable). There is no discounting.

\section{FIGURE 1 ABOUT HERE}

A firm will only continue its date- 0 investment until date 2 if it can meet the date- 1 liquidity need. If the liquidity need is not met, then the firm is liquidated and the project produces a cash flow equal to zero. The firm can manage its liquidity either using a bank credit line or cash holdings. As in Holmstrom and Tirole (1998), the firm holds cash by buying a riskless security (such as a Treasury bond) at date-0. The price of the bond is equal to $q$, which we take as exogenous and assume to be greater than one. Thus, to transfer cash across time the firm must pay a given liquidity premium, which is equal to $q-1>0$.

If the firm continues, the investment produces a date- 2 cash flow $\widehat{R}$ which obtains with probability $p$. With probability $1-p$, the investment produces nothing. The probability of success depends on the input of specific human capital by the firms' managers. If the managers exert high effort, the probability of success is equal to $p_{G}$. Otherwise, the probability is $p_{B}$, but the managers consume a private benefit equal to $\widehat{B}$. While the cash flow $\widehat{R}$ is verifiable, the managerial effort and the private benefit are neither verifiable nor contractible. Because of the moral hazard due this private benefit, managers must keep a high enough stake in the project to be induced to exert effort. We assume that the investment is negative NPV if the managers do not exert effort, implying the following incentive constraint:

$$
\begin{aligned}
p_{G} \widehat{R}_{M} & \geq p_{B} \widehat{R}_{M}+\widehat{B}, \text { or } \\
\widehat{R}_{M} & \geq \frac{\widehat{B}}{\Delta p},
\end{aligned}
$$

where $\widehat{R}_{M}$ is the managers' compensation and $\Delta p=p_{G}-p_{B}$. This moral hazard problem implies that the firms' cash flows cannot be pledged in their entirety to outside investors. We 
assume:

$$
\widehat{\rho_{0}} \equiv p_{G}\left(\widehat{R}-\frac{\widehat{B}}{\Delta p}\right)<\rho<\widehat{\rho_{1}} \equiv p_{G} \widehat{R} .
$$

The parameter $\widehat{\rho_{0}}$ represents the investment's pledgeable income, and $\widehat{\rho_{1}}$ its total expected payoff. Since $\widehat{\rho_{0}}<\rho$, the firm does not generate enough pledgeable income in the bad state of the world to fund the liquidity shock, though continuation is positive NPV $\left(\rho<\widehat{\rho_{1}}\right)$. This assumption creates a role for liquidity management.

The manager's choice of $\widehat{\lambda}$ impacts the project's cash flows and private benefits in the following way. If the manager chooses the illiquid project $\left(\widehat{\lambda}=\lambda^{\prime}\right)$, we have that $\widehat{R}=R^{\prime}$ and $\widehat{B}=B^{\prime}$. If the manager chooses the liquid project $(\widehat{\lambda}=\lambda)$, we have that $\widehat{R}=R$ and $\widehat{B}=B$. Finally, we have that $R^{\prime}>R$ and $B^{\prime}>B$. Thus, the illiquid project produces a higher cash flow when it is successful, and a higher associated private benefit. We make the following assumptions:

$$
\begin{gathered}
(1-\lambda) \rho_{1}<I<\rho_{1}-\lambda \rho, \\
\left(1-\lambda^{\prime}\right) \rho_{1}^{\prime}<I<\rho_{1}^{\prime}-\lambda^{\prime} \rho, \\
\rho_{0}^{\prime} \equiv p_{G}\left(R^{\prime}-\frac{B^{\prime}}{\Delta p}\right)=\rho_{0} \equiv p_{G}\left(R-\frac{B}{\Delta p}\right), \text { and } \\
\rho_{0}-\lambda^{\prime} \rho>I .
\end{gathered}
$$

The first and second assumptions mean that both the illiquid and the liquid projects have positive NPV, but only if the firm can continue the projects with positive probability in the liquidity state at date 1 . The third assumption is made for simplicity and to economize on notation. It says that both the liquid and the illiquid project produce the same ex-post pledgeable income $\rho_{0}$ (that is, $\widehat{R}$ and $\widehat{B}$ change in a way that leaves $\rho_{0}$ constant). But recall that since the liquid project requires a liquidity infusion with lower probability, ex-ante pledgeable income is larger for the liquid project. The fourth assumption then means that even the illiquid project generates enough pledgeable income to fund the initial investment (and thus the illiquid project is also feasible).

Suppose that the firm would like to choose the liquid investment (that is, $\rho_{1}-\lambda \rho>$ $\left.\rho_{1}^{\prime}-\lambda^{\prime} \rho\right)$. The problem that the firm faces in this case is that once it has written the initial contract to fund the investment and insure liquidity, it may have incentives to shift the funds into the illiquid investment ("illiquidity transformation") because the illiquid project produces higher payoff conditional on success, $\rho_{1}^{\prime}>\rho_{1}$. 
This signal $s$ is verifiable, so the bank can write contracts that are contingent on $s$. In particular, the bank can deny additional funding at date-1 if it observes a signal $s=s^{\prime}$, but still provide it if does not observe $s=s^{\prime}$. This suggests the following strategy. Conditional on the firm reporting a liquidity shock $\rho$, the bank can monitor to verify that the firm made the correct choice of $\lambda .{ }^{1}$ If the bank draws a signal $s=s^{\prime}$, then it will be optimal for the bank to deny additional funding since the firm's pledgeable income is $\rho_{0}<\rho$. If the bank does not monitor or if it does not draw a negative signal $s=s^{\prime}$, then it provides funding for the liquidity shock $\rho$ (this commitment can be guaranteed by a contract that binds the bank to finance the date- 1 investment unless it obtains the negative signal $s=s^{\prime}$ ). Figure 2 depicts the decision tree for the bank, assuming that the firm has chosen $\widehat{\lambda}=\lambda$.

\section{$\overline{\text { FIGURE } 2 \text { ABOUT HERE }}$}

In order to make sure that both the bank and the firm have the correct incentives under the monitored credit line we make the following assumptions:

$$
\mu\left(\rho-\rho_{0}\right)>c
$$

and

$$
[1-\lambda+\lambda(1-\mu)]\left(\rho_{1}-\rho_{0}\right)>\left(1-\lambda^{\prime}\right)\left(\rho_{1}^{\prime}-\rho_{0}\right)
$$

We can now state our first result in the following proposition, which we prove below:

Proposition 1 Given assumptions 2 to 8, the firm can implement the liquid investment $\widehat{(\lambda}=$ $\lambda)$ by opening a monitored credit line of size $\rho$ and commitment fee equal to $y=\lambda \frac{(1-\mu)\left(\rho-\rho_{0}\right)+c}{(1-\lambda)}$ with the bank. In addition, the firm raises enough external financing at date-0 to fund the initial investment $I$. The bank can revoke access to the credit line at date-1 if it monitors the firm (at a cost $c$ ) and obtains a signal $s=s^{\prime}$. The firm's payoff under the monitored credit line is $U^{L C}=\rho_{1}-\lambda \rho-I-\lambda\left[c+\mu\left(\rho_{1}-\rho\right)\right]$.

First, we show that the bank has incentives to monitor and deny access to the credit line if $s=s^{\prime}$, given that the firm follows the equilibrium strategy $(\widehat{\lambda}=\lambda)$. Then, we show that the firm indeed has incentives to pick $\widehat{\lambda}=\lambda$, and that the ex-ante feasibility constraint is obeyed.

Conditional on the liquidity shock, if the bank does not monitor it must honor the credit line and its payoff is $-\left(\rho-\rho_{0}\right)$ (see Figure 1 for the timeline that refers to bank's actions). This

\footnotetext{
${ }^{1}$ It does not make sense for the bank to monitor in the good state $(1-\lambda)$ since in that case the project produces a positive conditional payoff for both the firm and the bank.
} 
is because the maximum expected payment that the bank can extract in state $L$ is capped by pledgeable income $\rho_{0}$. In other words, if the date-2 liability generated by the credit line is $D^{L C}$, then it must be the case that $p_{G} D^{L C} \leq \rho_{0}$. If the bank does monitor, it obtains a signal $s=s^{\prime}$ with probability $\mu$ and it can deny access to the credit line. Its payoff is then $-(1-\mu)\left(\rho-\rho_{0}\right)-c$. So as long as $\mu\left(\rho-\rho_{0}\right)>c$ (equation 7 ), it is incentive compatible for the bank to monitor even when the bank anticipates that the firm has made the correct choice and picked $\widehat{\lambda}=\lambda$. Incentive compatibility is preserved because of the "negative NPV" feature of the date- 1 loan. In terms of a credit line, the bank loses money when the firm draws on the credit line. Thus, the optimal contract can rely on the bank's incentives to deny access to liquidity insurance (the credit line) in order to induce good behavior by the firm.

Given that the bank is expected to monitor, if the firm chooses the right project its payoff (after the initial contract is written) is:

$$
U_{b}=[1-\lambda+\lambda(1-\mu)]\left(\rho_{1}-\rho_{0}\right)
$$

The firm earns the rent $\rho_{1}-\rho_{0}$ upon continuation, but continuation only occurs with probability $(1-\mu)$ in state $\lambda$ (see Figure 1 for an illustration). If the borrower deviates from the equilibrium strategy and chooses $\lambda^{\prime}$ instead, the firm is liquidated with probability one in state $\lambda^{\prime}$ and the payoff is:

$$
U_{b}^{\prime}=\left(1-\lambda^{\prime}\right)\left(\rho_{1}^{\prime}-\rho_{0}\right)
$$

So if equation 8 holds, the borrower has the incentive to choose the correct project. Figure 3 depicts the firm's choice of $\widehat{\lambda}$, given the bank's monitoring strategy.

\section{FIGURE 3 ABOUT HERE}

Notice that in the absence of credit line revocation, the firm's payoff under the illiquid project after the initial contract is sunk would be $\left(\rho_{1}^{\prime}-\rho_{0}\right)$ which is greater than the payoff under the liquid investment $\left(\rho_{1}-\rho_{0}\right)$. Thus, revocation is essential to induce the choice of the liquid investment.

Finally, we show that the firm generates enough pledgeable income to fund the initial investment and the credit line, taking into account the monitoring technology. Since $y=$ $\lambda \frac{(1-\mu)\left(\rho-\rho_{0}\right)+c}{(1-\lambda)}$, the bank breaks even on the credit line (including the monitoring cost $c$ ). Let $D$ represent the additional payment that is promised to investors at date-2 (conditional on success). Limited pledgeability requires $y+p_{G} D \leq \rho_{0}$. To fund the initial investment, it must be that $(1-\lambda) p_{G} D \geq I$. Putting these conditions together we obtain:

$$
I+\lambda(1-\mu) \rho+\lambda c \leq(1-\lambda \mu) \rho_{0}
$$


The bank must now fund the monitoring $\operatorname{cost} c$ with probability $\lambda$. The firm is liquidated with probability $\lambda \mu$, and the credit line is used with probability $\lambda(1-\mu)$. Since $\mu\left(\rho-\rho_{0}\right)>c$, it can be shown that this condition is implied by that above $\left(\rho_{0}-\lambda^{\prime} \rho>I\right)$. Intuitively, monitoring is increasing equilibrium pledgeable income for the bank. The firm's payoff under the monitored credit line is then:

$$
U^{L C}=\rho_{1}-\lambda \rho-I-\lambda\left[c+\mu\left(\rho_{1}-\rho\right)\right] .
$$

The term $\lambda\left[c+\mu\left(\rho_{1}-\rho\right)\right]$ captures the effect of monitoring on the firm's payoff. The direct monitoring costs reduce the firm's ex-ante payoff. In addition, the firm is liquidated in state $\lambda \mu$ resulting in a loss of value $\left(\rho_{1}-\rho\right)$. As it is clear from this expression, the loss in value created by monitoring increases with the probability of the liquidity shock $\lambda$.

$U^{L C}$ is the firm's maximum possible payoff if it chooses to manage its liquidity using a monitored credit line. Given the analysis above, the only possible alternative for the firm is to pick the illiquid investment instead. In that case, we have the following result which we prove below:

Proposition 2 If the cost of holding cash is not too large, that is, if $\rho_{0}-\lambda^{\prime} \rho-I>(q-$ 1) $\left(\rho-\rho_{0}\right)$, the firm can implement the illiquid investment $\left.\widehat{(\lambda}=\lambda^{\prime}\right)$ by holding an amount of cash equal to $\left(\rho-\rho_{0}\right)$. The firm raises enough external financing at date-0 to fund the initial investment $I$ and the cash balance (by promising a payment equal to $D^{C}$ ), and continues the project at date 1 with probability equal to 1 . The firm's payoff under cash management is $U^{C}=\rho_{1}^{\prime}-\lambda^{\prime} \rho-I-(q-1)\left(\rho-\rho_{0}\right)$.

Since the firm holds cash equal to $\left(\rho-\rho_{0}\right)$, it can continue the project in state $\lambda^{\prime}$ in date 1 . It returns the cash to investors in state $\left(1-\lambda^{\prime}\right)$. Thus, investors date- 0 break even constraint is:

$$
I+q\left(\rho-\rho_{0}\right) \leq\left(1-\lambda^{\prime}\right)\left(p_{G} D^{C}+\rho-\rho_{0}\right),
$$

and limited pledgeability requires that $p_{G} D^{C} \leq \rho_{0}$. These two constraints imply that this strategy is feasible when $\rho_{0}-\lambda^{\prime} \rho-I>(q-1)\left(\rho-\rho_{0}\right)$, which holds if $q$ is low. The resulting payoff is the NPV of the illiquid investment, net of the cost of carrying cash, $U^{C}=$ $\rho_{1}^{\prime}-\lambda^{\prime} \rho-I-(q-1)\left(\rho-\rho_{0}\right) .^{2}$

\footnotetext{
${ }^{2}$ One may wonder whether the firm can replace cash holdings with a non-monitored credit line of same size and thereby avoid the liquidity premium. The problem with this alternative is that since monitoring is conditionally efficient for the bank $\left(\mu\left(\rho-\rho_{0}\right)>c\right)$, the bank will always have incentives to monitor when the firm reports a liquidity shock. Thus, unless the bank can perfectly commit not to monitor, the firm risks being liquidated with probability one in state $\lambda^{\prime}$. By condition 4, it is then not worth investing in the project. Thus, the firm pays the liquidity premium as a way of self-insuring against a liquidity shock that happens with high probability at date 1.
} 
The next result follows from Propositions 1 and $2:^{3}$

Corollary 1 The firm chooses the monitored credit line when $U^{L C}>\max \left(0, U^{C}\right)$ and it chooses cash holdings when $U^{C}>\max \left(0, U^{L C}\right)$. If $\max \left(U^{L C}, U^{C}\right)<0$, the project never starts.

This corollary suggests that cash-based liquidity management will tend to be associated with illiquid projects that require frequent liquidity infusions. Firms that endogenously choose to invest in projects with high liquidity risk will find it optimal to self-insure against such shocks, while firms that choose to invest in projects with low liquidity risk manage liquidity through a monitored credit line to ensure that they do not engage in illiquidity transformation after the bank has provided liquidity insurance. In this sense, the model generates an equilibrium relationship between liquidity risk and liquidity management - firms with high liquidity risk manage liquidity through cash holdings. We next show that the link between liquidity risk and liquidity management extends to a case in which firms are ex-ante heterogeneous with respect to liquidity risk.

\subsection{Introducing heterogeneity in liquidity risk}

Suppose that there are now two types of firms that we call $L$ and $H$. Firm $L$ has lower liquidity risk than firm $H$ irrespective of project choice, that is, $\widehat{\lambda}_{L}<\widehat{\lambda}_{H}$ (which is equivalent to saying that $\lambda_{L}<\lambda_{H}$ and $\lambda_{L}^{\prime}<\lambda_{H}^{\prime}$ ). This difference in liquidity risk can be interpreted as arising from firm characteristics such as the risk of the underlying business and the correlation between cash flows and investment needs. Specifically we make the following assumption:

$$
\lambda_{j}^{\prime}=\lambda_{j}+t, \text { for } j=L, H .
$$

This assumption means that the effect of illiquidity transformation on the probability of the liquidity shock is the same for both types of firm. As we show below, this assumption is sufficient but not necessary for our results - all that is needed is that the potential increase in illiquidity risk is not much larger for firms of type $H$.

Given this assumption, the following result follows from the analysis in the previous section:

Proposition 3 Firms with low liquidity risk (type L) are more likely to choose credit lines for liquidity management, while firms with high liquidity risk (type $H$ ) are more likely to choose cash.

\footnotetext{
${ }^{3}$ Notice that we cannot guarantee that $U^{L C}$ and $U^{C}$ will be positive, net of the costs of liquidity management. If they are negative then the project does not start, since by assumptions 3 and 4 the projects have negative NPV unless they can be continued with positive probability in the liquidity state in date 1.
} 
As explained in Corollary 1, the choice between cash and credit lines is driven by the difference between $U^{C}$ and $U^{L C}$. For firms of type $L$ :

$$
\begin{aligned}
\left(U^{C}-U^{L C}\right)_{L} & =\rho_{1}^{\prime}-\lambda_{L}^{\prime} \rho-(q-1)\left(\rho-\rho_{0}\right)-\rho_{1}+\lambda_{L} \rho+\lambda_{L}\left[c+\mu\left(\rho_{1}-\rho\right)\right]= \\
& =\rho_{1}^{\prime}-\rho_{1}+\lambda_{L}\left[c+\mu\left(\rho_{1}-\rho\right)\right]-t \rho-(q-1)\left(\rho-\rho_{0}\right)
\end{aligned}
$$

Similarly, for firms of type $H$ :

$$
\left(U^{C}-U^{L C}\right)_{H}=\rho_{1}^{\prime}-\rho_{1}+\lambda_{H}\left[c+\mu\left(\rho_{1}-\rho\right)\right]-t \rho-(q-1)\left(\rho-\rho_{0}\right) .
$$

Thus, we have that:

$$
\left(U^{C}-U^{L C}\right)_{H}-\left(U^{C}-U^{L C}\right)_{L}=\left(\lambda_{H}-\lambda_{L}\right)\left[c+\mu\left(\rho_{1}-\rho\right)\right]>0 .
$$

Thus, the difference in payoffs is larger for firms of type $H$ which are then more likely to choose cash. ${ }^{4}$

The intuition for this result is straightforward. As the probability of the liquidity shock increases, monitoring becomes increasingly expensive due to the direct monitoring cost and the necessary revocation of credit line access (which provides incentives for the firm to not engage in illiquidity transformation). Thus, firms with high liquidity risk prefer to avoid monitored liquidity insurance and use cash for liquidity management.

\subsection{Variable date-0 investment}

The model above assumes a fixed investment level $I$. We will now show that allowing firms to also choose the level of the date- 0 investment gives rise to additional empirical implications.

In order to do so, we assume that firms can choose an investment level $I \epsilon(0, \infty)$ at date $0 .^{5}$ The project produces cash flows that are proportional to the level of investment, such that the project's pledgeable income is $\widehat{\rho_{0}} I$, and the expected payoff is $\widehat{\rho_{1}} I$. The date- 1 liquidity shock is also a multiple of the date- 0 investment level, $\widehat{\rho} I$. The structure of the model is very similar to that above, with the following changes. Firms are now endowed with initial wealth $A$ (as we will see investment is a multiple of initial wealth). We maintain assumptions 2, 5, ??, 7 and 8 . In addition, we make the following assumptions:

$$
\rho_{1}-\lambda \rho-1-\lambda\left[c+\mu\left(\rho_{1}-\rho\right)\right]>0
$$

\footnotetext{
${ }^{4}$ If we eliminate assumption 13 , there would be an additional term in equation 14 equal to $\left[\left(\lambda_{L}^{\prime}-\lambda_{L}\right)-\right.$ $\left.\left(\lambda_{H}^{\prime}-\lambda_{H}\right)\right] \rho$. Thus, as long as the difference $\left(\lambda_{H}^{\prime}-\lambda_{H}\right)$ is not significantly larger than $\left(\lambda_{L}^{\prime}-\lambda_{L}\right)$ the result will continue to hold.

${ }^{5}$ This version of the model is the same that is used in Holmstrom and Tirole (1998).
} 


$$
\begin{gathered}
\rho_{1}^{\prime}-\lambda^{\prime} \rho-1-(q-1)\left(\rho-\rho_{0}\right)>0, \text { and } \\
1-\rho_{0}+\lambda \rho+\lambda\left[c-\mu\left(\rho-\rho_{0}\right)\right]>0 .
\end{gathered}
$$

Assumptions 15 and 16 mean that both the liquid and the illiquid investment have positive NPV per unit of investment, net of monitoring costs (in the case of the liquid investment) and the liquidity premium (the illiquid investment). Assumption 17 will assure that investment levels are finite, as we will see. It basically says that the pledgeable income per unit of liquid investment is lower than one. Since the pledgeable income of the illiquid investment is lower than that of the liquid one, this assures that both investment levels remain finite. ${ }^{6}$

Given these assumptions, the following proposition considers the implementation of the liquid project in this version of the model:

Proposition 4 The firm can implement the liquid investment $(\widehat{\lambda}=\lambda)$ by opening a monitored credit line of size $\rho I^{L C}$ and commitment fee equal to $y=\lambda \frac{(1-\mu)\left(\rho-\rho_{0}\right)+c}{(1-\lambda)} I^{L C}$ with the bank. The date-0 investment level is $I^{L C}=\frac{1}{1-\rho_{0}+\lambda \rho+\lambda\left[c-\mu\left(\rho-\rho_{0}\right)\right]} A$, and the payoff $U^{L C}=$ $\left[\rho_{1}-\lambda \rho-1-\lambda\left(c+\mu\left(\rho_{1}-\rho\right)\right)\right] I^{L C}$. The firm raises external financing at date- 0 to fund the initial investment $I^{L C}$. The bank can revoke access to the credit line at date-1 if it monitors the firm (at a cost $c$ ) and obtains a signal $s=s^{\prime}$.

The proof is virtually identical to that for Proposition 1. Assumption 7 means that the bank has incentives to monitor at date-1 (monitoring increases pledgeable income). Assumption 8 assures that the firm has incentives to pick the liquid investment given that it expects monitoring. The bank breaks even on the credit line given a commitment fee equal to $y$. The date-0 budget constraint is:

$$
\begin{aligned}
I^{L C}-A & =\left(\rho_{0}-\lambda \rho-\lambda\left[c-\mu\left(\rho-\rho_{0}\right)\right]\right) I^{L C} \text { or } \\
I^{L C} & =\frac{1}{1-\rho_{0}+\lambda \rho+\lambda\left[c-\mu\left(\rho-\rho_{0}\right)\right]} A .
\end{aligned}
$$

Given assumption $17, I^{L C}$ is finite. The firm's payoff is then given by:

$$
U^{L C}=\left[\rho_{1}-\lambda \rho-1-\lambda\left(c+\mu\left(\rho_{1}-\rho\right)\right)\right] I^{L C},
$$

which is positive given assumption 15 .

Next, the following proposition considers implementation of the illiquid project:

\footnotetext{
${ }^{6}$ To see this, notice that:

$$
1-\rho_{0}+\lambda \rho+\lambda\left[c-\mu\left(\rho-\rho_{0}\right)\right]<1-\rho_{0}+\lambda \rho<1-\rho_{0}+\lambda^{\prime} \rho<1-\rho_{0}+\lambda^{\prime} \rho+(q-1)\left(\rho-\rho_{0}\right),
$$
}

so that the pledgeable income per unit of illiquid investment $\left(1-\rho_{0}+\lambda^{\prime} \rho+(q-1)\left(\rho-\rho_{0}\right)\right)$ is also lower than one. The first inequality holds because of assumption 7 (so that bank monitoring is time consistent). 
Proposition 5 The firm can implement the illiquid investment $\left(\widehat{\lambda}=\lambda^{\prime}\right)$ by holding an amount of cash equal to $\left(\rho-\rho_{0}\right) I^{C}$. The date-0 investment level is $I^{C}=\frac{1}{1-\rho_{0}+\lambda^{\prime} \rho+(q-1)\left(\rho-\rho_{0}\right)} A$. The firm raises enough external financing at date-0 to fund the initial investment $I$ and the cash balance, and continues the project at date 1 with probability equal to 1 . The firm's payoff under cash management is $U^{C}=\left[\rho_{1}^{\prime}-\lambda^{\prime} \rho-1-(q-1)\left(\rho-\rho_{0}\right)\right] I^{C}$.

The proof is identical to that for Proposition 2. Notice that assumption 17 together with the inequalities in 18 assure that $I^{C}$ is finite. Given assumption $16, U^{C}>0$. Then, the next result follows from Propositions 4 and 5:

Corollary 2 The firm chooses the monitored credit line when $U^{L C}>U^{C}$, and it chooses cash holdings when $U^{C}>U^{L C}$.

While the structure of the variable investment model is very similar to that of the fixed investment version, it gives rise to additional implications. These implications follow from the fact that pledgeable income per unit of investment is larger for the liquid investment (the inequality in 18). This inequality, coupled with Corollary 2, gives rise to the following results:

1. The level of investment is larger when the firm chooses the monitored credit line, that is, $I^{L C}>I^{C}$

2. If the illiquid investment is chosen by the firm, its payoff per unit of investment must be larger than that of the liquid investment, that is, $\frac{U^{C}}{I^{C}}>\frac{U^{L C}}{I^{L C}}$.

Result 1 follows directly from inequality 18, and the expressions for investment $I^{C}$ and $I^{L C}$. Result 2 follows from corollary 2 and result 1 . Given that $I^{C}<I^{L C}$, the firm will only choose the illiquid investment if its payoff per unit is higher than that of the liquid investment, that is, $\frac{U^{C}}{I^{C}}>\frac{U^{L C}}{I^{L C}}$.

In other words, the choice between the liquid and the illiquid projects is equivalent to a choice between pledgeability and productivity. The liquid project has greater pledgeability, and allows the firm to increase investment levels. Thus, the illiquid project will only be chosen in equilibrium when its payoff per unit of investment (or the productivity of investment) is larger than that of the liquid project.

\subsection{Liquidity management for good times}

The model above assumes that firms need liquidity in a bad state of the world (one in which internal cash flows are low, so that the firm must fund a liquidity shortfall equal to $\rho$ ). 
However, as shown by Froot, Scharfstein and Stein (1993) it is also possible that firms may need additional funding capacity in a good state of the world, in which internal cash flows are high but the firm needs to fund an investment opportunity with low pledgeable income. We can explore the consequences of this type of liquidity need in the model above, by considering the following framework.

\section{$\overline{\text { FIGURE } 4 \text { ABOUT HERE }}$}

Consider the fixed investment model of Section 2.1, but with the following modifications (see Figure 4 for a timeline). First, assume that in the liquidity state $\hat{\lambda}$, it is no longer profitable to continue either type of project:

$$
\rho>\rho_{1}^{\prime}
$$

Second, the firm may now have an additional investment opportunity in the good state of the world, state $(1-\hat{\lambda})$. This investment opportunity requires an investment of $\tau$. Assume that this investment is positive NPV but that it generates zero pledgeable income:

$$
\rho_{\tau}>\tau
$$

where $\rho_{\tau}$ is the payoff at the final date, none of which is pledgeable to outside investors. ${ }^{7}$ The new opportunity is available with (conditional) probability $\nu$ in state $(1-\hat{\lambda})$. In addition, the firm's original investment produces pledgeable income $\rho_{0}$ and total income $\widehat{\rho_{1}}$, as above (the timeline is illustrated in the Figures 1-4).

Given these assumptions, the firm no longer needs liquidity in the bad state of the world (it will be liquidated). However, it may need liquidity in the good state of the world, if the new investment opportunity becomes available. The firm can use the pledgeable income from the original project $\left(\rho_{0}\right)$ to fund the new investment opportunity, but that may not be enough. If $\rho_{0} \geq \tau$, then the firm is financially unconstrained and will not demand liquidity. To make the analysis interesting we maintain the following assumption:

$$
\rho_{0}<\tau
$$

Let us consider first a case in which the liquid project is optimal. As we will see below, in this version of the model this assumption is immaterial because credit lines will be optimal irrespective of the firm's optimal project choice. Specifically, we assume that:

$$
(1-\lambda) \rho_{1}>\left(1-\lambda^{\prime}\right) \rho_{1}^{\prime}
$$

\footnotetext{
${ }^{7}$ We note that this zero pledgeability assumption is only for simplicity. It is straightforward to generalize the model for a case in which the new opportunity generates positive pledgeable income.
} 
The firm's payoff in state $\hat{\lambda}$ is equal to zero. In addition, the new investment opportunity's expected payoff in state $(1-\widehat{\lambda})$ is $\nu\left(\rho_{\tau}-\tau\right)$. Since this payoff arises in the state with no liquidity shock, the presence of the new opportunity can only increase the advantage of the liquid investment over the illiquid one (since $1-\lambda>1-\lambda^{\prime}$ ). Thus, assumption 23 means that either the firm invests in the liquid project, or it does not start at all. We assume that the liquid project is profitable if the firm can also undertake the new opportunity:

$$
(1-\lambda)\left[\rho_{1}+\nu\left(\rho_{\tau}-\tau\right)\right]>I
$$

We now state the main result of this section:

Proposition 6 If $I+(1-\lambda) \nu\left(\tau-\rho_{0}\right) \leq(1-\lambda)(1-\nu) \rho_{0}$, the firm can undertake the new investment opportunity by opening a fully committed credit line of size $\tau-\rho_{0}$ and commitment fee equal to $y^{\tau}=\nu \frac{\left(\tau-\rho_{0}\right)}{(1-\nu)}$ with the bank. In addition, the firm raises enough external financing at date-0 to fund the initial investment $I$. The firm's payoff under the credit line is $U^{\tau}=$ $(1-\lambda)\left[\rho_{1}+\nu\left(\rho_{\tau}-\tau\right)\right]-I$. This credit line strictly dominates cash holdings if the liquidity premium $(q-1)$ is positive.

Note that in this version of the model, state $\lambda$ is no longer relevant. The firm produces zero pledgeable income and a zero payoff in state $\lambda$ due to assumption 20 . To undertake the investment opportunity in state $(1-\lambda) \nu$ it requires additional pledgeable income equal to $\left(\tau-\rho_{0}\right)$. This income is provided by the fully committed credit line. Given the commitment fee $y^{\tau}$, which is paid out in state $(1-\lambda)(1-\nu)$, the bank breaks even on the credit line. In addition, let $D^{\tau}$ be the payment promised to date- 0 investors. The limited pledgeability constraint implies that the commitment fee plus the expected payment to date- 0 investors must be lower than $\rho_{0}$ in state $(1-\lambda)(1-\nu)$. Thus, we have that:

$$
p D^{\tau}+y^{\tau} \leq \rho_{0}
$$

In addition, the expected payment to date- 0 investors must be sufficient to fund the date- 0 investment:

$$
(1-\lambda)(1-\nu) p D^{\tau} \geq I
$$

Putting these two conditions together, we obtain the condition that $I+(1-\lambda) \nu\left(\tau-\rho_{0}\right) \leq$ $(1-\lambda)(1-\nu) \rho_{0}$.

In addition, notice that the firm has no incentives to engage in illiquidity transformation in this version of the model. Since $(1-\lambda) \rho_{1}>\left(1-\lambda^{\prime}\right) \rho_{1}^{\prime}$, increasing the probability of the liquidity shock brings no benefit to the firm. In addition, doing so reduces the probability that the firm can invest in the new opportunity. 
Given that monitoring is not an issue, both credit lines and cash would work equally well to provide liquidity for good times. However, if there is even a small cost of carrying cash (such as a small liquidity premium), then the firm is going to prefer a credit line. To see this, notice that the firm would need to hold an amount of cash equal to $\left(\tau-\rho_{0}\right)$. Thus, even if this is feasible to do, the firm's payoff would be reduced by an amount equal to $(q-1)\left(\tau-\rho_{0}\right)$. That is, a credit line should dominate cash if the firm's goal is to transfer pledgeable income into a good state of the world. ${ }^{8}$

Finally, consider what happens if we drop assumption 23. In particular, let $\rho_{1}^{\prime}$ be large enough such that the illiquid project becomes optimal for the firm, even after accounting for the new investment opportunity:

$$
\left(1-\lambda^{\prime}\right)\left[\rho_{1}^{\prime}+\nu\left(\rho_{\tau}-\tau\right)\right]>(1-\lambda)\left[\rho_{1}+\nu\left(\rho_{\tau}-\tau\right)\right]
$$

Unlike in the model of Sections 2.1 to 2.3, this change has no implication for the firm's optimal liquidity policy which continues to be a fully committed credit line. The size and commitment fees remain the same (since both drawdowns and fee payments happen in the noliquidity state), and the credit line is feasible as long as $I+\left(1-\lambda^{\prime}\right) \nu\left(\tau-\rho_{0}\right) \leq\left(1-\lambda^{\prime}\right)(1-\nu) \rho_{0}$. Thus, the fully committed credit line is optimal even when the firm wants to implement the illiquid project instead of the liquid one.

\section{Empirical implications}

This simple framework is consistent with several empirical facts documented by the literature on liquidity management. It also generates additional implications. First, let us list the implications for which there is existing empirical support:

1. Firms that use credit lines for liquidity management tend to be larger, more tangible, and to have lower $Q s$ than those that use cash for liquidity management: Notice that these implications come mostly from the variable investment model.

2. Credit line contracts contain covenants contingent on firm profitability, and access to credit lines is sometimes restricted when firm profitability decreases: In the model, this

\footnotetext{
${ }^{8}$ This point is similar to that made by Acharya, Almeida and Campello (2007), but these authors do not explicitly model a credit line. Almeida, Campello and Hackbarth (2011) show that a related argument can explain why credit lines are used more frequently in industries with a greater incidence of distressed acquisitions (which they call "liquidity mergers"). A distressed acquisition is a likely example of an investment opportunity that arrives in a good state of the world (for the acquirer), but that has low pledgeable income (due to the target's financial distress).
} 
pattern is part of an optimal liquidity management policy that discourages credit line users to engage in illiquidity transformation. Importantly, this feature of credit line contracts is not incompatible with credit lines' role as liquidity insurance.

In fact, the model also makes the following prediction which simultaneously helps establish credit lines' role as liquidity insurance:

3. Credit line drawdowns tend to happen following decreases in firm profitability.

A key implication of the model is that firms with low liquidity risk are more likely to use credit lines rather than cash for liquidity management. This suggests the following implications:

4. Credit line drawdowns are relatively infrequent, so that credit line drawdowns to meet liquidity needs are significantly less frequent that reductions in cash holdings to meet liquidity needs: This implication comes from the result that the firms that use credit lines are the ones that are least likely to need their liquidity.

5. Firms that use credit lines for liquidity management have higher credit ratings than those that use cash for liquidity management: Credit ratings are not a perfect proxy for liquidity risk, but they should capture at least some of that, notably the ease of accessing public bond markets.

All of the implications above come from a model in which firms manage liquidity for bad times. In addition, for firms that manage liquidity for good times we have the following implication:

6. Firms that need additional liquidity in good states of the world should use credit lines to do so, and such firms with a high correlation between cash flows and investment opportunities (low hedging-needs firms) should be more likely to use credit lines rather than cash.

A possible empirical proxy for the firm's hedging needs is the correlation between cash flows and investment opportunities (as in Acharya, Almeida and Campello, 2007). There are two challenges, however, regarding testing this implication: first, firms with high correlations between cash flows and investment opportunities have a natural hedge and are likely to be unconstrained. These firms would need little or no liquidity management, rather than need 
credit lines. Second, it is difficult to measure the pledgeability of new investment opportunities. If these new opportunities can be funded in the spot market, then again the firm needs no liquidity management. In contrast, it is more natural to argue that the firm will have difficulty raising external funds in bad times (when it is hit by a negative liquidity shock).

Interestingly, the survey paper by Lins, Servaes and Tufano (2010) suggests that according to managers credit lines are used to fund future growth opportunities while cash is used as precautionary savings. Implication 6 is consistent with this piece of survey evidence. In addition, Disatnik, Duchin and Schmidt (2010) show that firms that find it easier to hedge cash flows (due to the nature of their business) are more likely to use credit lines for liquidity management. One explanation for this finding is that cash flow hedging handles liquidity management for bad times for hedgers, but not for non-hedgers. In other words, hedgers use credit lines to manage liquidity for good times, while non-hedgers use credit lines to manage liquidity for bad times.

Finally, our model also has predictions for the relationship between hedging needs and covenants in credit line contracts.

7. Credit lines for low hedging-needs firms are less likely to contain covenants than credit lines for high hedging-needs firms: This implication arises from the model's result that covenants play no economic role when firms demand liquidity for good times. In the model there are only two types of firms (those that demand liquidity for good times and those that demand liquidity in bad times), and thus the choice of covenant is dichotomous (credit line contracts either have covenants or they don't). In the data, the distinction across firm types is likely to be less stark. Thus, we examine the incidence of covenants as a function of measures of hedging needs (the correlation between cash flows and investment opportunities).

A related implication is that:

8. Low hedging-needs firms are less likely to violate covenants of bank credit lines than high hedging-needs firms.

Implications 7 and 8 are closely related but not identical since banks have to determine whether a firm is in violation of a credit line covenant or not.

\section{Empirical tests}

In this section we present our empirical analysis. 


\subsection{Sample Construction and Description}

We obtain firm-level data from the Capital IQ (CIQ) and Compustat databases for the period of 2002-2008. We restrict ourselves to U.S. firms covered on both databases and traded on AMEX, NASDAQ, or NYSE. We remove utilities (SIC codes 4900-4999) and financial firms (SIC codes 6000-6999). Following Bates, Kahle and Stulz (2009), we further remove firmyears with negative revenues, and negative or missing assets, obtaining in the end a sample of 23,013 firm-years involving 4,248 unique firms.

CIQ compiles detailed information on capital structure and debt structure by going through financial footnotes contained in firms' $10 \mathrm{~K}$ Securities and Exchange Commission (SEC) filings. Most importantly for our purposes, firms provide detailed information on the drawn and undrawn portions of their lines of credit in the liquidity and capital resources section under the management discussion, or in the financial footnotes explaining debt obligations, and CIQ compiles this data. We use the information of CIQ to construct a dummy for the presence of a credit line, which is equal to one if the firm has a positive amount of undrawn credit reported in the 10K. Following Sufi (2009) we also construct a measure of the amount of undrawn credit expressed as a percentage of book assets (Compustat item 6).

We also compute the following variables that are known to be relevant for line of credit holdings behavior. Cash as a percentage of assets is computed as cash and short-term investments (item 1) over assets (item 6). As in Sufi (2009), size is measured as the logarithm of assets minus cash and short term investments. Book leverage is debt in current liabilities (item 34) plus long-term debt (item 9) over assets. Net working capital to assets is computed as the difference between working capital (item 179) and cash and investments (item 1) divided by assets. R\&D expenses are computed as the ratio of research and development expenses (item 46) over sales (item 12). Industry cash-flow risk (named industry sigma) is the mean cash-flow volatility computed by two-digit SIC code. Cash-flow volatility is the standard deviation of operating income before depreciation (item 13) calculated over the previous twelve quarters and scaled by assets. Dividend payout dummy is a dummy that takes value of one if common stock has paid dividends (item 21).

Following Lemmon, Roberts and Zender (2008), we compute profitability as operating income before depreciation (item 13) over assets. Market-to-book (M/B) is the sum of the market value of equity, total debt, and preferred stock at liquidating value (item 10), minus deferred taxes and investment tax credit (item 35), all divided by assets. Market value of equity is computed as stock price (item 199) times number of common shares used to calculate the earnings per share (item 54). Total debt is current liabilities (item 34) plus long-term 
debt (item 9). Tangibility is net property, plant and equipment (item 8) over assets.

We also compute firm-year rating as the average monthly rating by S\&P (item 280), after converting the S\&P rating into numbers. Credit spread is the spread on U.S. corporate bond yields between Moody's AAA and BAA provided by Datastream, based on averages of seasoned issues. We compute the firm's asset (unlevered) beta, calculated from equity (levered) betas and a Merton-KMV formula as in Acharya, Almeida and Campello (2010). Finally, following standard procedures, all variables are winsorized at the $0.5 \%$ in both tails of the distribution.

\subsection{Implication 1: Ex-ante determinants of credit lines}

Our first empirical prediction suggests that firms that use LCs for liquidity management should be larger, more tangible, and have lower $Q s$ than firms that rely on cash for liquidity management. We examine this predictions in Tables 1 and 2 .

Table 1 provides univariate evidence on the differences in firm characteristics across the samples of firms with and without a LC. In columns (1)-(2) we report mean and median values for the entire sample, while columns (3)-(4) and (5)-(6) contain values for the sub-samples of firms with and without a LC, respectively. Firms with a LC have a median size that is approximately 4.7 times larger than firms without a LC. Median tangibility for firms with a $\mathrm{LC}$ is $20.2 \%$ while for firms without a $\mathrm{LC}$ is $9.1 \%$. Proxying for $Q$ with the M/B, firms with a $\mathrm{LC}$ have M/B of 1.2 while this ratio is 1.6 for firms without a LC. The t- and Mann-Withney tests show that the differences in values across the two samples are statistically significant. These findings offer univariate support to our first empirical prediction.

More generally, Table 1 allows for a broad comparison of firms with and without a LC. The main picture that emerges from the table is that the sample of firms with a LC is significantly different from the rest along all the dimensions reported in the table. Firms with LC are more profitable, more leveraged, are more likely to pay dividends, have lower beta, and are more likely to be rated. These firms also invest more in working capital and capex, but have lower R\&D expenses. Overall, these characteristics suggest that firms with a LC are more established, mature firms with fewer growth opportunities and more stable cash flows. Table 1 is also informative on the relative sizes of LCs and cash across the two samples. First, column (3) shows that the mean value of LCs as a percentage of assets is of a comparable magnitude to cash. Second, measuring liquidity as the sum of cash plus undrawn credit divided by assets, the mean liquidity of firms with a LC is significantly lower than that of firms without a LC (respectively, $27.5 \%$ of assets, and $40.5 \%) .{ }^{9}$

\footnotetext{
${ }^{9}$ This basic finding is not affected by how we measure assets. If we measure CLs and cash as percentages
} 


\section{TABLE 1 ABOUT HERE}

In Table 2 we provide multivariate evidence in support to our first empirical prediction. The choice of firm characteristics builds on the factors that have been identified to be relevant for cash holdings (Opler, Pinkowitz, Stulz and Williamson (1999)), for LCs (Sufi (2009) and Acharya, Almeida and Campello (2009)) and for capital structure (Lemmon, Roberts, and Zender (2008)). The sets of controls suggested by these literatures largely overlap.

\section{TABLE 2 ABOUT HERE}

We start by running a Probit regression in which the dependent variable is a dummy for the presence of a LC (column (1)). Consistent with our first empirical prediction, this regression shows that firms are more likely to carry a LC if they are larger, have lower $Q$, and higher tangibility (all three significant at the $1 \%$ level). This result shows that the results of Table 1 also hold in a multivariate setting.

Next, we perform some robustness checks. It is possible that what we are capturing is an alternative mechanism based on agency costs or asymmetry of information through which these factors are related to the presence of a LC. For example, it could be that a large, wellrated, low MB, safe firm is more likely to be granted a LC by a bank because it is easier to monitor. To deal with this concern, in columns (2) and (3) we restrict the sample to rated firms, and this way we better isolate our mechanism by only studying firms who are very likely to be able to get a LC but who may prefer to rely mostly on cash for liquidity management.

A related but distinct concern is that given that LC are relatively cheap to open, it may be a good approximate description to say that any firm that is able to be granted one will apply for one, even if it plans to rely mostly on cash. What may matter most instead is the amount of cash holdings the firm then goes on to accumulate relative to undrawn credit. For this reason, studying the extensive margin (presence of a LC) might be misleading, so in columns (3) and (4) we run two regressions where the dependent variable is the share of cash in total liquidity (cash + undrawn LC). To better study the intensive margin in column (4) we restrict the sample to rated firms with a LC. Finally, we also add a regression with Cash/Assets for robustness. The results on Q and tangibility are robust to all specifications, while the positive association between size and the presence of LC is not present when studying the intensive margin.

of non-cash assets, using medians (means are affected by a high proportion of outliers (Sufi(2009)) we obtain that CLs represent $8.5 \%$ of non-cash assets, while cash represents $12.5 \%$ of non-cash assets, in the sub-sample of firms with a CL. Cash consists of $62.7 \%$ of non-cash assets for the sub-sample of firms without a CL. 


\subsection{Implication 2: Profitability and credit line revocations}

In Table 3 we focus on the relationship between profitability and restriction of access to credit lines. We limit the sample to firms that have a credit line in period $t-1$, and study whether access to the line of credit is restricted during period $t$. We first run probit regressions where the dependent variable takes value 1 if a firm had a line of credit in $t-1$ but not in $t$. For robustness, we also consider the possibility that a restriction of access is partial and does not

lead to a complete revocation. For this purpose, we run OLS regressions of the change in undrawn credit (with the opposite sign, i.e. if undrawn credit decreases the variable takes a positive sign), and probit regressions where the dependent variable takes value 1 if undrawn credit has dropped by more than 30\% and drawn credit. For each regression specification we provide three different definitions of profitability: the standard definition of profitability computed as operating income before depreciation, scaled by assets; a dummy for profitability being positive; and a dummy for profitability being above $5 \%$.

The results show that credit lines tend to get revoked following decreases in profitability (column (1)-(3)). At the mean, a decrease in profitability equivalent to $10 \%$ of assets is associated with an increase in the likelihood of having a line of credit revocation of $6.6 \%$. In general, access to undrawn credit depends negatively on profitability, as shown in columns (4)-(6). By excluding reductions in undrawn credit that are smaller than $30 \%$, columns (7)-(9) show that the negative relationship between undrawn credit and profitability is not driven by small, insignificant variations in undrawn credit, but it is actually associated with large reductions.

In unreported tests, we also exclude the possibility that the loss (total or partial) of the line of credit is due to a drawdown rather than to a revocation or a reduction. For this purpose, in all regressions we require that the firm does not draw down on the line of credit in year $t$. All the above results carry through in this alternative specification.

TABLE 3 ABOUT HERE

\subsection{Implication 3: Evidence on credit line drawdowns}

We now examine the relationship between credit line drawdowns and profitability. As explained above, if credit lines are monitored liquidity insurance, drawdowns should be negatively related to profitability. Although a decrease in profitability tends to reduce access to credit lines and may lead to a revocation (as shown in the previous section), we still expect credit lines to be used by firms as a source of liquidity following a shortfall in cash flows. 


\section{TABLE 4 ABOUT HERE}

The results of this analysis are presented in Table 4 . We regress the annual variation in revolving credit on several measures of profitability and on a set of controls. In addition to the measures of profitability employed in Table 3, we now control for the change in profitability, measured as the difference between profitability in year $t$ minus profitability in year $t-1$. We also construct one variable for the positive changes in profitability (increases in profitability) and one for the negative changes (decreases in profitability).

All regressions show a negative and significant relationship between profitability and variations in total drawn lines of credit, as predicted by the monitoring model. This evidence shows that an increase in revolving credit is associated with a drop in profitability, and it suggests that credit lines are employed by firms to withstand liquidity shocks resulting from a shortfall in cash flows.

\section{TABLE 4 ABOUT HERE}

For robustness, we also run unreported tests in which we restrict variations in revolving credit to be positive. In this way, we can better isolate the variations in revolving credit that arise from a drawdown, from the variations that arise from repayments. We also run a specification in which the dependent variable takes value zero if the change in revolving credit is non-positive. The results obtained in these additional regressions confirm the above results.

\subsection{Implications 4-5: Probability of liquidity events and liquidity policy}

The model predicts (Implication 4) that firms that use credit lines for liquidity management should have low liquidity risk. We first test this prediction by comparing the frequency of low profit realizations for firms with and without a credit line. In particular, we compare the frequency of profitability being below $0 \%$ and $5 \%$. The evidence, reported in Panel A of Table 5 , shows that on average credit line users are significantly less likely to face a negative or low profitability shock.

Next, we examine the probability that firms with and without credit lines use their liquidity to meet a shortfall in cash flows. For this purpose, we construct a new variable which is a dummy that takes the value of one when a drawdown occurs during a period in which profitability is negative. We then calculate the frequency of this event (liquidity event) in the sample of firms with a LC. To compare this with firms that do not use credit lines, we 
calculate a similar variable for cash drawdowns, and compare both frequencies. The evidence is reported in Panel B. In line with the empirical prediction of the model, liquidity events associated with drawdowns of credit lines are significantly less frequent than liquidity events associated with reductions in cash holdings. This result suggests that liquidity risk is lower for credit line users, than for firms that use cash for liquidity management.

\section{TABLE 5 ABOUT HERE}

Figure 5 provides further non-parametric support to the above finding. The figure illustrates the distribution of profitability for firms with and without a line of credit ( $L C$ firms and cash firms, respectively). The evidence is consistent with Table 5, in that firms that use cash have a higher probability of experiencing liquidity events.

\section{FIGURE 5 ABOUT HERE}

And, consistent with Implication 5, Figure 6 shows that firms that have a LC indeed tend to have higher credit rating compared to firms that do not have a LC and use cash for liquidity management instead. Less than $10 \%$ of firms without a LC have a rating, while more than $30 \%$ of firms with a LC have one.

\section{FIGURE 6 ABOUT HERE}

\subsection{Liquidity management and hedging needs}

In this section we test the predictions of the model regarding the relationship between hedging needs and a firm's liquidity policy.

Hedging needs are defined as the correlation between investment opportunities and firmlevel cash flows, and are calculated at the 3-digit SIC code industry level. To estimate investment opportunities, we build on Acharya, Almeida and Campello (2007) and Duchin (2010) and construct the following measures (for definitions of variables see Table A1 in the Appendix):

1. Median industry annual investing activities;

2. Median industry market-to-book ratio (Tobin's Q).

We envisage that for financially constrained firms, at the firm level cash flows are endogenously related with investment and therefore with Tobin's Q. To address this problem, we calculate investment opportunities using only data for financially unconstrained firms. Firms

are defined to be financially unconstrained if they pay dividends, have assets above $\$ 500 \mathrm{~m}$ and rating above $\mathrm{B}+$. 


\subsubsection{Implication 6: Hedging needs and the use of lines of credit}

We first test the empirical prediction that firms that need liquidity for good times (low hedging needs) are more likely to use lines of credit instead of cash for liquidity management. Table 6 compares several measures of liquidity policy by sorting firms into high and low hedging needs categories. The table displays the differences in the presence of a line of credit, the amount of undrawn credit as a share of assets, the share of cash in total liquidity, and total revolving credit over assets. In Panel A we calculate the raw statistics for the four liquidity variables across the sample of high and low hedging needs firms. In Panel B we carry out a similar exercise, however this time we relate hedging needs with the residuals obtained from the regressions in Table 2. By looking at regression residuals, rather than the raw variables, we can evaluate the relationship between hedging needs and the four liquidity variables after controlling for the firm characteristics of Table 2.

The evidence of Table 6 is consistent with the prediction of the model, according to which firms with low hedging needs are significantly more likely to use credit lines rather than cash for liquidity management. Low hedging needs firms have more undrawn credit as a percentage of assets, and as a percentage of total liquidity. Low hedging needs firm also have a higher percentage of revolving credit as a percentage of assets.

TABLE 6 ABOUt HerE

\subsubsection{Implication 7: Hedging needs and the use of covenants}

Table 7 estimates the relationship between bank monitoring and hedging needs. As a proxy of bank monitoring, we employ covenants on credit lines. We obtain data on covenants from LPC Dealscan. We list all the covenants attached to credit lines for the firms in our sample during the period 2002-2008. In most cases, firms are granted several new credit line facilities in the same year. For these cases we report the median number of covenant across facilities.

We use four measures of covenant intensity. We borrow the first measure from Demiroglu and James (2010), itself based on the covenant intensity index originally introduced by Bradley and Roberts (2004). This index consists of covenants that limit the actions of the borrower, or give lenders rights that are contingent on adverse future events. The index is composed of six types of covenants: asset sales sweeps, collateral releases, debt issuance sweeps, dividend restrictions, a dummy for financial covenants, and equity issuance sweeps. ${ }^{10}$ Our second

\footnotetext{
${ }^{10}$ The dummy for financial covenants takes value one if at least two of the following covenants are included: Debt/Tangible Assets, Max Capex, Max Debt/Assets, Max Debt/Ebitda, Max Debt/Equity, Max Leverage, Max Senior Debt/Ebitda, Max Senior Leverage, Min Change Interest Coverage, Min Current Ratio, Min Debt
} 
measure of covenant intensity is based on the covenant index of Drucker and Puri (2009) which is computed as the sum of all the covenants included in a loan agreement. ${ }^{11}$ This index differs from that of Demiroglu and James (2010) primarily in that it gives equal weight to all covenants. Our third measure of covenant intensity focuses on the covenants that relate directly to cash flows. These covenants primarily require minimum profitability levels, minimum interest coverage ratios, and restrictions on cash flow usage. ${ }^{12}$ Our fourth measure of covenant intensity is based on the presence of sweeps, such as asset sale sweeps, debt issuance sweeps, and excess cash-flow sweeps. These covenants impose restrictions to managers payout and reinvestment policy, giving preference to debt reimbursement over other possible uses of cash flows. ${ }^{13}$

\section{TABLE 7 ABOUT HERE}

In Table 7 we run a set of Poisson regressions using our four covenant intensity measures as dependent variables. Among the explanatory variables, the variables of main interest are the two hedging measures already employed in Table 6, the first one based on investment activities and the second one on Tobin's Q. We also control for a set of variables identified by Demiroglu and James (2010) as relevant for the use of covenants.

According to our model, we should expect a positive relationship between the intensity of covenants and hedging needs, meaning that credit lines for low hedging needs firms tend to carry fewer covenants. The evidence provided in Table 7 suggests that this is the case, as covenants are less prevalent for firms that have high correlation between cash flows and investment opportunities (low hedging needs firms).

Coverage, Min Ebitda, Min Equity/Asset, Min Fixed Charge, Min Interest Coverage, Min Net Worth/Assets, Min Quick Ratio, Net Worth, Other Ratio, Other, Tangible Net Worth.

${ }^{11}$ The index is computed as the sum of the following covenants (dummy equal to one if covenant is present): \% Of Excess CF, \% Of Net Income, Asset Sales Sweep, Collateral Release, Debt Issuance Sweep, Dividend Restrictions, Equity Issuance Sweep, Excess CF Sweep, Insurance Proceeds Sweep, Max Capex, Max Debt/Assets, Max Debt/Ebitda, Max Debt/Equity, Max Debt/Tangible Assets, Max Leverage, Max Senior Debt/Ebitda, Max Senior Leverage, Min Change Interest Coverage, Min Current Ratio, Min Debt Coverage, Min Ebitda, Min Equity/Asset, Min Fixed Charge, Min Interest Coverage, Min Net Worth/Assets, Min Quick Ratio, Net Worth, Other, Other Ratio, Tangible Net Worth.

${ }^{12}$ More precisely our cash flow covenant index is computed as the sum of the following covenants (dummy equal to one if covenant is present): \% Of Excess CF, \% Of Net Income, Excess CF Sweep, Max Capex, Max Debt/Ebitda, Max Senior Debt/Ebitda, Min Change Interest Coverage, Min Ebitda.

${ }^{13}$ More precisely, this covenant index is obtained as the sum of the following covenants (dummy equal to one if covenant is present): Asset Sales Sweep, Debt Issuance Sweep, Equity Issuance Sweep, Excess CF Sweep, Insurance Proceeds Sweep. 


\subsubsection{Implication 8: Hedging needs and covenant violations}

Finally, we turn our attention to covenant violations. We obtain data on covenant violations from the website of Amir Sufi. The database contains quarterly financial covenant violation data and is employed in Nini, Smith and Sufi (2010) for the analysis of creditor control rights. Importantly, the data contain violations on covenants on any type of debt and not only on credit lines. With this caveat in mind, we regard the violations of covenants in general as a proxy for the violation of covenants on credit lines. We annualize the violation data and consider a violation to have occurred if at least in one quarter a violation has been observed.

Table 8 provides our results on the analysis of the relationship between covenant violation and hedging needs of firms, using a Probit estimation. The dependent variable is a dummy for the presence of at least one covenant violation during that year. For the explanatory variables we borrow from Demiroglu and James (2010) and Nini, Smith and Sufi (2010). As from Table 7, firms with high hedging needs carry a larger number of covenants, we include the covenant index of Drucker and Puri (2009) as an extra control variable.

As predicted by the model, the evidence of Table 8 suggests that covenant violations are less common for firms that have high correlation between cash flows and investment opportunities (low hedging needs firms), also after controlling for the presence of covenants (which is lower for these firms as shown in Table 7).

\section{TABLE 8 ABOUT HERE}

\section{Conclusions}

Recent empirical and survey evidence on corporate liquidity management suggests that bank credit lines do not offer fully committed liquidity insurance, and that they are frequently used to finance future growth opportunities rather than for precautionary motives. In this paper, we propose and test a theory of corporate liquidity management that is consistent with these findings. We argue that a corporate credit line can be understood as a form of monitored liquidity insurance, which controls illiquidity-seeking behavior by firms through bank monitoring and credit line revocation. In addition, we allow firms to demand liquidity not to hedge against negative liquidity shocks, but to help finance future growth opportunities. We show that bank monitoring and credit line revocation play less of a role for such firms, because the nature of their liquidity demand reduces their incentives to engage in illiquidityseeking behavior. Thus, firms that have low hedging-needs (e.g., high correlation between cash flows and investment opportunities) can access fully committed credit lines that dominate cash 
holdings as an optimal liquidity management tool.

We use a novel dataset on corporate credit lines to provide empirical evidence that is consistent with the predictions of the model. The evidence suggests that credit line users have lower liquidity risk than firms that use cash for liquidity management. In addition, firms with low hedging needs are more likely to use credit lines for liquidity management. Credit line covenants and covenant violations are less common when the credit line user has low hedging needs.

There are several interesting avenues for future research. One is the empirical relationship between the ex-post reported purpose of line of credit drawdowns and the presence of covenants. Another is the aftermath of a covenant violation, and in particular the factors that determine whether covenants are waived or whether they instead generate a line of credit revocation. Finally, material adverse clauses (MACs) are another way through which banks may carry out their monitoring activity. More theoretical and empirical research on these topics could shed further light on the relationship between illiquidity transformation and bank monitoring, and more generally on firms' choice of liquidity management instruments. 


\section{References}

Acharya, V., H. Almeida, and M. Campello, 2007, "Is Cash Negative Debt? A Hedging Perspective on Corporate Financial Policies," Journal of Financial Intermediation 16, 515-554.

Almeida, H., M. Campello, and M. Weisbach, 2004, "The Cash Flow Sensitivity of Cash," Journal of Finance 59, 1777-1804.

Bates, T. W., K. M. Kahle, and R. M. Stulz, 2009. "Why Do U.S. Firms Hold So Much More Cash than They Used To?," Journal of Finance 64(5), 1985-2021.

Bradley, M., and M. R. Roberts. 2004. The Structure and Pricing of Corporate Debt Covenants. Working Paper, Duke University.

Campello, M., E. Giambona, J. Graham, and C. Harvey, 2010, "Liquidity Management and Corporate Investment During a Financial Crisis," Working Paper, University of Illinois, University of Amsterdam, and Duke University.

Demiroglu, C., and C. James, 2010, "The information content of bank loan covenants," Review of Financial Studies, 23 (10): 3700-3737.

Disatnik, D., R. Duchin and B. Schmidt, 2010, "Cash Flow Hedging and Liquidity Choices," Working Paper, Tel Aviv University, Michigan University, and Emory University.

Drucker, S., and M. Puri, 2009. "On Loan Sales, Loan Contracting, and Lending Relationships," Review of Financial Studies 22(7), 2635-2672.

Duchin, R., 2010, "Cash Holdings and Corporate Diversification," Journal of Finance 65, 955-992.

Holmstrom, B., and J. Tirole, 1997, "Financial Intermediation, Loanable Funds, and the Real Sector," Quarterly Journal of Economics 112, 663-691.

Holmstrom, B., and J. Tirole, 1998, "Private and Public Supply of Liquidity," Journal of Political Economy 106, 1-40.

Lemmon, M. L., M. R. Roberts, and J. F. Zender, 2008. "Back to the Beginning: Persistence and the Cross-Section of Corporate Capital Structure," Journal of Finance 63(4), 15751608.

Lins, K., H. Servaes, and P. Tufano, 2010, "What Drives Corporate Liquidity? An International Survey of Strategic Cash and Lines of Credit," forthcoming, Journal of Financial Economics.

Nini, G., D. C. Smith, and A. Sufi, 2010, "Creditor Control Rights and Firm Investment Policy", Working Paper

Opler, T., L. Pinkowitz, R. Stulz, and R. Williamson, 1999, "The Determinants and Implications of Corporate Cash Holdings," Journal of Financial Economics 52, 3-46. 
Shockley, R., and A. Thakor, 1997, "Bank Loan Commitment Contracts: Data, Theory and Tests," Journal of Money, Credit and Banking 29, 517-534.

Sufi, A., 2009, "Bank Lines of Credit in Corporate Finance: An Empirical Analysis," Review of Financial Studies 22, 1057-1088.

Tirole, J., 2006, The Theory of Corporate Finance, Princeton University Press.

Yun, H., 2009, "The Choice of Corporate Liquidity and Corporate Governance," forthcoming, Review of Financial Studies. 
Table 1

Sample Overview: Comparison of Firms with and without Undrawn Credit

This table provides summary statistics for the entire sample and for the restricted samples of firms with and without a credit line. The entire sample consists of non-utilities (excluding SIC codes 4900-4949) and non-financials (excluding SIC codes 6000-6999) U.S. firms covered by both Capital IQ and Compustat from 2002 to 2008. We have removed firm- years with 1) negative revenues, and 2) negative or missing assets. After the above filters, the sample consists of 23,013 firm-year observations involving 4,248 unique firms. Table A1 provides a description of the variables listed below. In this table, "size" is measured as the book value of assets expressed in millions of 2001 dollars deflated by the consumer price index. All variables are winsorized at the $0.5 \%$ in both tails of the distribution. The last two columns test for differences between samples with and without undrawn credit using the unequal variances t-test and the two-sample Wilcoxon rank-sum (Mann-Whitney) test.

\begin{tabular}{|c|c|c|c|c|c|c|c|c|}
\hline & (1) & (2) & (3) & (4) & (7) & (8) & (9) & (10) \\
\hline & \multicolumn{2}{|c|}{ Entire Sample } & \multicolumn{2}{|c|}{$\begin{array}{l}\text { Sample of Firms } \\
\text { with a Credit Line }\end{array}$} & \multicolumn{2}{|c|}{$\begin{array}{c}\text { Sample of Firms } \\
\text { without a Credit } \\
\text { Line }\end{array}$} & \multicolumn{2}{|c|}{$\begin{array}{l}\text { Test of Difference } \\
\text { with vs. without a } \\
\text { Credit Line }\end{array}$} \\
\hline & Mean & Median & Mean & Median & Mean & Median & $\begin{array}{c}\text { t-test } \\
\text { p-value }\end{array}$ & $\begin{array}{c}\text { MW } \\
\text { p-value }\end{array}$ \\
\hline Undrawn Credit Lines/At & 0.091 & 0.061 & 0.134 & 0.107 & - & - & - & - \\
\hline Cash/ At & 0.226 & 0.131 & 0.141 & 0.078 & 0.405 & 0.386 & $\begin{array}{l}76.397 \\
(0.000)\end{array}$ & $\begin{array}{l}70.993 \\
(0.000)\end{array}$ \\
\hline Profitability & 0.055 & 0.107 & 0.115 & 0.124 & -0.072 & 0.036 & $\begin{array}{l}-44.059 \\
(0.000)\end{array}$ & $\begin{array}{l}-53.049 \\
(0.000)\end{array}$ \\
\hline Size & 2086.7 & 281.9 & 2673.9 & 470.0 & 852.0 & 100.5 & $\begin{array}{l}-23.278 \\
(0.000)\end{array}$ & $\begin{array}{l}-51.556 \\
(0.000)\end{array}$ \\
\hline Book Leverage & 0.208 & 0.147 & 0.236 & 0.197 & 0.151 & 0.015 & $\begin{array}{l}-24.890 \\
(0.000)\end{array}$ & $\begin{array}{l}-42.623 \\
(0.000)\end{array}$ \\
\hline $\mathrm{M} / \mathrm{B}$ & 1.799 & 1.303 & 1.575 & 1.205 & 2.308 & 1.621 & $\begin{array}{l}25.145 \\
(0.000)\end{array}$ & $\begin{array}{l}26.630 \\
(0.000)\end{array}$ \\
\hline Tangibility & 0.243 & 0.163 & 0.275 & 0.202 & 0.176 & 0.091 & $\begin{array}{r}-32.666 \\
(0.000)\end{array}$ & $\begin{array}{l}-40.200 \\
(0.000)\end{array}$ \\
\hline NWC/At & 0.047 & 0.039 & 0.082 & 0.071 & -0.026 & -0.017 & $\begin{array}{l}-37.129 \\
(0.000)\end{array}$ & $\begin{array}{l}-39.597 \\
(0.000)\end{array}$ \\
\hline Capex/At & 0.053 & 0.032 & 0.057 & 0.035 & 0.045 & 0.023 & $\begin{array}{l}-13.482 \\
(0.000)\end{array}$ & $\begin{array}{l}-27.773 \\
(0.000)\end{array}$ \\
\hline $\mathrm{R} \& \mathrm{D} /$ Sales & 0.734 & 0.005 & 0.106 & 0.000 & 2.065 & 0.118 & $\begin{array}{l}20.432 \\
(0.000)\end{array}$ & $\begin{array}{l}58.710 \\
(0.000)\end{array}$ \\
\hline Dividend Payer & 0.280 & 0.000 & 0.360 & 0.000 & 0.107 & 0.000 & $\begin{array}{l}-47.635 \\
(0.000)\end{array}$ & $\begin{array}{l}-39.423 \\
(0.000)\end{array}$ \\
\hline Beta KMV & 1.279 & 1.119 & 1.177 & 1.038 & 1.530 & 1.381 & $\begin{array}{l}15.360 \\
(0.000)\end{array}$ & $\begin{array}{l}15.544 \\
(0.000)\end{array}$ \\
\hline Rating Dummy & 0.263 & 0.000 & 0.347 & 0.000 & 0.085 & 0.000 & $\begin{array}{l}-52.301 \\
(0.000)\end{array}$ & $\begin{array}{l}-42.178 \\
(0.000)\end{array}$ \\
\hline Observations & \multicolumn{2}{|c|}{23013} & \multicolumn{2}{|c|}{15596} & \multicolumn{2}{|c|}{7417} & & \\
\hline
\end{tabular}


Table 2

What Determines the Presence and Size of Credit Lines

This table relates firm characteristics to various liquidity measures. In column (1) and (2) we run probit regressions for the presence of a credit line, where the dependent variable is a dummy that takes value one, if the firm has an undrawn credit line. Column (1) is for all the firms in the sample, while column (2) is for the sub-sample of rated firms (>CCC). In columns (3) and (4) we run OLS regressions for cash and short-term investments as a percentage of total liquidity. Total liquidity is computed as cash and short-term investments plus undrawn credit. Column (3) is for sub-sample of rated firms ( $>\mathrm{CCC}$ ), while column (4) is for the sub-sample of rated firms that have a credit line. In column (5) we run an OLS regression for cash and short-term investments as a percentage of total assets, on the subsample of rated firms $(>\mathrm{CCC})$ with a credit line. Year and Exchange fixed effects included. Robust standard errors clustered at the firm level are reported in parentheses. See Table A1 for further descriptions of the variables. ***, **, and $*$ denote statistical significance at the $1 \%, 5 \%$, and $10 \%$ levels, respectively.

\begin{tabular}{|c|c|c|c|c|c|}
\hline & (1) & (2) & (3) & (4) & (5) \\
\hline & \multicolumn{2}{|c|}{$\begin{array}{l}\text { Presence of a Credit Line } \\
\text { (Dummy) }\end{array}$} & \multicolumn{2}{|c|}{$\begin{array}{c}\text { Cash/ } \\
\text { Total Liquidity }\end{array}$} & Cash/At \\
\hline & All Firms & Rated & Rated & Rated with a LC & Rated with a LC \\
\hline Profitability & $\begin{array}{c}0.484 * * * \\
(0.151)\end{array}$ & $\begin{array}{l}1.733 * * \\
(0.691)\end{array}$ & $\begin{array}{c}-0.523 * * * \\
(0.088)\end{array}$ & $\begin{array}{c}-0.279 * * * \\
(0.089)\end{array}$ & $\begin{array}{l}-0.058 \\
(0.036)\end{array}$ \\
\hline Size & $\begin{array}{c}0.150^{* * *} \\
(0.019)\end{array}$ & $\begin{array}{c}0.002 \\
(0.048)\end{array}$ & $\begin{array}{c}0.020 * * * \\
(0.007)\end{array}$ & $\begin{array}{c}0.026 * * * \\
(0.007)\end{array}$ & $\begin{array}{c}0.000 \\
(0.002)\end{array}$ \\
\hline Book Leverage & $\begin{array}{c}0.877 * * * \\
(0.112)\end{array}$ & $\begin{array}{c}0.818^{* * *} \\
(0.260)\end{array}$ & $\begin{array}{c}-0.280 * * * \\
(0.039)\end{array}$ & $\begin{array}{c}-0.234 * * * \\
(0.037)\end{array}$ & $\begin{array}{c}-0.113 * * * \\
(0.013)\end{array}$ \\
\hline $\mathrm{M} / \mathrm{B}$ & $\begin{array}{c}-0.057^{* * *} \\
(0.016)\end{array}$ & $\begin{array}{c}-0.299 * * * \\
(0.059)\end{array}$ & $\begin{array}{c}0.093 * * * \\
(0.010)\end{array}$ & $\begin{array}{c}0.069 * * * \\
(0.010)\end{array}$ & $\begin{array}{c}0.035 * * * \\
(0.005)\end{array}$ \\
\hline Tangibility & $\begin{array}{c}0.988 * * * \\
(0.167)\end{array}$ & $\begin{array}{l}-0.132 \\
(0.318)\end{array}$ & $\begin{array}{c}-0.121^{* *} \\
(0.054)\end{array}$ & $\begin{array}{c}-0.116^{* *} \\
(0.051)\end{array}$ & $\begin{array}{c}-0.073 * * * \\
(0.014)\end{array}$ \\
\hline NWC/Assets & $\begin{array}{c}1.860 * * * \\
(0.139)\end{array}$ & $\begin{array}{c}1.114 * * * \\
(0.351)\end{array}$ & $\begin{array}{c}-0.543 * * * \\
(0.061)\end{array}$ & $\begin{array}{c}-0.468 * * * \\
(0.056)\end{array}$ & $\begin{array}{c}-0.184 * * * \\
(0.022)\end{array}$ \\
\hline Capex/Assets & $\begin{array}{c}0.654 \\
(0.403)\end{array}$ & $\begin{array}{l}1.338 \\
(1.165)\end{array}$ & $\begin{array}{c}-0.376^{* * *} \\
(0.134)\end{array}$ & $\begin{array}{c}-0.359 * * * \\
(0.114)\end{array}$ & $\begin{array}{l}-0.033 \\
(0.028)\end{array}$ \\
\hline R\&D/Sales & $\begin{array}{l}-0.001 \\
(0.008)\end{array}$ & $\begin{array}{c}-2.713 * * * \\
(0.875)\end{array}$ & $\begin{array}{c}0.007 * * * \\
(0.002)\end{array}$ & $\begin{array}{c}0.849 * * * \\
(0.178)\end{array}$ & $\begin{array}{c}0.270 * * * \\
(0.093)\end{array}$ \\
\hline Dividend Payer & $\begin{array}{l}0.215^{* * *} \\
(0.054)\end{array}$ & $\begin{array}{c}0.093 \\
(0.101)\end{array}$ & $\begin{array}{c}-0.062 * * * \\
(0.015)\end{array}$ & $\begin{array}{c}-0.052 * * * \\
(0.014)\end{array}$ & $\begin{array}{l}-0.002 \\
(0.005)\end{array}$ \\
\hline CF Volatility & $\begin{array}{l}1.075 \\
(0.698)\end{array}$ & $\begin{array}{l}-4.068 \\
(3.396)\end{array}$ & $\begin{array}{c}1.665 * * * \\
(0.525)\end{array}$ & $\begin{array}{l}1.010^{* *} \\
(0.484)\end{array}$ & $\begin{array}{c}0.896 * * * \\
(0.202)\end{array}$ \\
\hline Beta KMV & $\begin{array}{c}-0.043^{* * *} \\
(0.011)\end{array}$ & $\begin{array}{l}-0.024 \\
(0.033)\end{array}$ & $\begin{array}{c}0.027 * * * \\
(0.005)\end{array}$ & $\begin{array}{c}0.027 * * * \\
(0.004)\end{array}$ & $\begin{array}{c}0.008 * * * \\
(0.002)\end{array}$ \\
\hline Rating (minus) & $\begin{array}{l}0.012 * * \\
(0.006)\end{array}$ & $\begin{array}{l}0.061^{* *} \\
(0.025)\end{array}$ & $\begin{array}{c}-0.010 * * * \\
(0.004)\end{array}$ & $\begin{array}{c}-0.012 * * * \\
(0.003)\end{array}$ & $\begin{array}{c}-0.004 * * * \\
(0.001)\end{array}$ \\
\hline $\begin{array}{l}\text { Observations } \\
\text { (Pseudo) R2 }\end{array}$ & $\begin{array}{c}16,873 \\
0.304\end{array}$ & $\begin{array}{l}4,410 \\
0.288\end{array}$ & $\begin{array}{l}4,770 \\
0.346\end{array}$ & $\begin{array}{l}4,338 \\
0.348\end{array}$ & $\begin{array}{l}4,338 \\
0.410\end{array}$ \\
\hline
\end{tabular}


Table 3: The Relationship between Profitability and Restriction of Access to Credit lines

This table presents Probit and OLS regression results to study the relationship between profitability and restriction of access to credit lines. In columns (1)-(3) the dependent variable is a dummy for the incidence of full credit line revocation. Columns (4)-(6) display OLS regression results in which the dependent variable is the decrease in undrawn credit availability as a $\%$ of firm assets. In columns (7)-(8) the dependent variable is a dummy for a decrease in undrawn credit greater than $30 \%$ of the outstanding amount. Year, Rating and Exchange fixed effects included. Rating fixed effects are based on 22 rating dummies and the unrated dummy. Robust standard errors clustered at the firm level are reported in parentheses. See Table $\mathrm{A} 1$ for further descriptions of the variables. ***, **, and * denote statistical significance at the $1 \%, 5 \%$, and $10 \%$ levels. All regressions include a constant term (unreported)

\begin{tabular}{|c|c|c|c|c|c|c|c|c|c|}
\hline & \multicolumn{3}{|c|}{$\begin{array}{l}\text { Revocation of Credit Line } \\
\text { (Dummy) }\end{array}$} & \multicolumn{3}{|c|}{ Decrease in Undrawn Credit } & \multicolumn{3}{|c|}{$\begin{array}{c}\text { Reduction in Undrawn Credit } \\
\text { (Dummy) }\end{array}$} \\
\hline Profitability & $\begin{array}{c}-0.649 * * * \\
(0.212)\end{array}$ & & & $\begin{array}{c}-0.035^{* * *} \\
(0.011)\end{array}$ & & & $\begin{array}{c}-0.836^{* * *} \\
(0.222)\end{array}$ & & \\
\hline Profits $>0 \%$ & & $\begin{array}{l}-0.453 * * * \\
(0.080)\end{array}$ & & & $\begin{array}{c}-0.010^{* *} \\
(0.004)\end{array}$ & & & $\begin{array}{c}-0.338 * * * \\
(0.052)\end{array}$ & \\
\hline Profits $>5 \%$ & & & $\begin{array}{c}-0.406^{* * *} \\
(0.067)\end{array}$ & & & $\begin{array}{c}-0.014 * * * \\
(0.003)\end{array}$ & & & $\begin{array}{c}-0.350 * * * \\
(0.041)\end{array}$ \\
\hline Size & $\begin{array}{l}-0.024 \\
(0.027)\end{array}$ & $\begin{array}{l}-0.010 \\
(0.027)\end{array}$ & $\begin{array}{l}-0.015 \\
(0.026)\end{array}$ & $\begin{array}{l}-0.001 \\
(0.001)\end{array}$ & $\begin{array}{l}-0.001 \\
(0.001)\end{array}$ & $\begin{array}{l}-0.000 \\
(0.001)\end{array}$ & $\begin{array}{c}0.001 \\
(0.013)\end{array}$ & $\begin{array}{c}0.002 \\
(0.013)\end{array}$ & $\begin{array}{c}0.003 \\
(0.013)\end{array}$ \\
\hline Book Leverage & $\begin{array}{c}-0.721^{* * *} \\
(0.184)\end{array}$ & $\begin{array}{c}-0.655^{* * *} \\
(0.170)\end{array}$ & $\begin{array}{c}-0.615^{* * *} \\
(0.171)\end{array}$ & $\begin{array}{c}0.020 * * * \\
(0.005)\end{array}$ & $\begin{array}{c}0.021 * * * \\
(0.005)\end{array}$ & $\begin{array}{c}0.022 * * * \\
(0.005)\end{array}$ & $\begin{array}{c}0.550 * * * \\
(0.098)\end{array}$ & $\begin{array}{c}0.603 * * * \\
(0.092)\end{array}$ & $\begin{array}{c}0.622 * * * \\
(0.094)\end{array}$ \\
\hline $\mathrm{M} / \mathrm{B}$ & $\begin{array}{c}0.071 * * * \\
(0.019)\end{array}$ & $\begin{array}{c}0.072 * * * \\
(0.018)\end{array}$ & $\begin{array}{c}0.080 * * * \\
(0.018)\end{array}$ & $\begin{array}{l}-0.001 \\
(0.001)\end{array}$ & $\begin{array}{l}-0.001 * \\
(0.001)\end{array}$ & $\begin{array}{l}-0.001 \\
(0.001)\end{array}$ & $\begin{array}{l}-0.008 \\
(0.020)\end{array}$ & $\begin{array}{l}-0.020 \\
(0.013)\end{array}$ & $\begin{array}{l}-0.012 \\
(0.014)\end{array}$ \\
\hline Tangibility & $\begin{array}{l}-0.053 \\
(0.202)\end{array}$ & $\begin{array}{c}-0.026 \\
(0.198)\end{array}$ & $\begin{array}{c}-0.046 \\
(0.195)\end{array}$ & $\begin{array}{c}-0.022 * * * \\
(0.005)\end{array}$ & $\begin{array}{c}-0.024 * * * \\
(0.005)\end{array}$ & $\begin{array}{c}-0.023 * * * \\
(0.005)\end{array}$ & $\begin{array}{c}-0.327^{* * *} \\
(0.091)\end{array}$ & $\begin{array}{c}-0.353 * * * \\
(0.091)\end{array}$ & $\begin{array}{c}-0.344 * * * \\
(0.091)\end{array}$ \\
\hline NWC/Assets & $\begin{array}{c}-1.332 * * * \\
(0.182)\end{array}$ & $\begin{array}{c}-1.257 * * * \\
(0.181)\end{array}$ & $\begin{array}{c}-1.255^{* * *} \\
(0.180)\end{array}$ & $\begin{array}{c}-0.018 * * * \\
(0.005)\end{array}$ & $\begin{array}{c}-0.020 * * * \\
(0.005)\end{array}$ & $\begin{array}{c}-0.017 * * * \\
(0.005)\end{array}$ & $\begin{array}{c}-0.589^{* * *} \\
(0.101)\end{array}$ & $\begin{array}{c}-0.603 * * * \\
(0.096)\end{array}$ & $\begin{array}{c}-0.562 * * * \\
(0.096)\end{array}$ \\
\hline Capex/Assets & $\begin{array}{c}-1.611^{* *} \\
(0.757)\end{array}$ & $\begin{array}{c}-1.677 * * \\
(0.742)\end{array}$ & $\begin{array}{c}-1.490 * * \\
(0.721)\end{array}$ & $\begin{array}{c}0.082 * * * \\
(0.020)\end{array}$ & $\begin{array}{c}0.077 * * * \\
(0.019)\end{array}$ & $\begin{array}{c}0.080 * * * \\
(0.019)\end{array}$ & $\begin{array}{c}1.552 * * * \\
(0.298)\end{array}$ & $\begin{array}{c}1.438 * * * \\
(0.289)\end{array}$ & $\begin{array}{c}1.537 * * * \\
(0.289)\end{array}$ \\
\hline R\&D/Sales & $\begin{array}{l}-0.001 \\
(0.007)\end{array}$ & $\begin{array}{c}0.002 \\
(0.006)\end{array}$ & $\begin{array}{c}0.003 \\
(0.006)\end{array}$ & $\begin{array}{c}0.000 \\
(0.000)\end{array}$ & $\begin{array}{c}0.000 \\
(0.000)\end{array}$ & $\begin{array}{c}0.000 \\
(0.000)\end{array}$ & $\begin{array}{l}-0.003 \\
(0.007)\end{array}$ & $\begin{array}{c}0.003 \\
(0.007)\end{array}$ & $\begin{array}{c}0.004 \\
(0.007)\end{array}$ \\
\hline Div. Payer Dummy & $\begin{array}{c}-0.253 * * * \\
(0.076)\end{array}$ & $\begin{array}{c}-0.244 * * * \\
(0.077)\end{array}$ & $\begin{array}{c}-0.229 * * * \\
(0.077)\end{array}$ & $\begin{array}{l}0.003 * \\
(0.002)\end{array}$ & $\begin{array}{c}0.002 \\
(0.002)\end{array}$ & $\begin{array}{l}0.003 * \\
(0.002)\end{array}$ & $\begin{array}{c}-0.092 * * * \\
(0.033)\end{array}$ & $\begin{array}{c}-0.103 * * * \\
(0.032)\end{array}$ & $\begin{array}{c}-0.091 * * * \\
(0.033)\end{array}$ \\
\hline Industry Sigma & $\begin{array}{c}2.714 \\
(1.890)\end{array}$ & $\begin{array}{l}3.163^{*} \\
(1.889)\end{array}$ & $\begin{array}{c}2.583 \\
(1.818)\end{array}$ & $\begin{array}{l}-0.060 \\
(0.049)\end{array}$ & $\begin{array}{c}-0.061 \\
(0.050)\end{array}$ & $\begin{array}{l}-0.068 \\
(0.049)\end{array}$ & $\begin{array}{c}1.026 \\
(0.927)\end{array}$ & $\begin{array}{c}1.041 \\
(0.936)\end{array}$ & $\begin{array}{c}0.793 \\
(0.930)\end{array}$ \\
\hline Beta KMV & $\begin{array}{c}0.049 * * \\
(0.022)\end{array}$ & $\begin{array}{c}0.048 * * \\
(0.022)\end{array}$ & $\begin{array}{c}0.046 * * \\
(0.022)\end{array}$ & $\begin{array}{c}0.002 * * \\
(0.001)\end{array}$ & $\begin{array}{c}0.002 * * * \\
(0.001)\end{array}$ & $\begin{array}{c}0.002 * * \\
(0.001)\end{array}$ & $\begin{array}{c}0.031 * * \\
(0.012)\end{array}$ & $\begin{array}{c}0.031 * * \\
(0.012)\end{array}$ & $\begin{array}{c}0.030 * * \\
(0.012)\end{array}$ \\
\hline $\begin{array}{l}\text { Observations } \\
\text { R-squared }\end{array}$ & 9,930 & 9,930 & 9,930 & $\begin{array}{c}10,244 \\
0.013\end{array}$ & $\begin{array}{c}10,244 \\
0.011\end{array}$ & $\begin{array}{c}10,244 \\
0.013\end{array}$ & 10,238 & 10,238 & 10,238 \\
\hline
\end{tabular}


Table 4: The Relationship between Profitability and Drawdowns on Credit lines

This table presents regression results to study the relationship between profitability and drawdowns of credit lines. The dependent variable is the annual variation in drawn credit lines. Profits $>0 \%$ and Profits $>5 \%$ are dummies for profitability being respectively above $0 \%$ and 5\%. Year, Rating and Exchange fixed effects included. Rating fixed effects are based on 22 rating dummies and the unrated dummy. Robust standard errors clustered at the firm level are reported in parentheses. See Table A1 for further descriptions of the variables. $* * *, * *$, and $*$ denote statistical significance at the $1 \%, 5 \%$, and $10 \%$ levels, respectively.

\begin{tabular}{|c|c|c|c|c|c|}
\hline & (1) & (2) & (3) & (4) & $(5)$ \\
\hline & \multicolumn{5}{|c|}{ Changes in Revolving Credit } \\
\hline Profitability & $\begin{array}{c}-0.022 * * * \\
(0.008)\end{array}$ & & & & \\
\hline Profits $>0 \%$ & & $\begin{array}{c}-0.008 * * * \\
(0.002)\end{array}$ & & & \\
\hline Profits $>5 \%$ & & & $\begin{array}{c}-0.009 * * * \\
(0.002)\end{array}$ & & \\
\hline Change in Profitability & & & & $\begin{array}{c}-0.056^{* * *} \\
(0.013)\end{array}$ & \\
\hline Increases in Profitability & & & & & $\begin{array}{c}-0.055 * * * \\
(0.017)\end{array}$ \\
\hline Decreases in Profitability & & & & & $\begin{array}{c}-0.057 * * \\
(0.025)\end{array}$ \\
\hline Size & -0.000 & -0.000 & 0.000 & -0.000 & -0.000 \\
\hline Book Leverage & $\begin{array}{c}(0.000) \\
0.029 * * *\end{array}$ & $\begin{array}{c}(0.000) \\
0.030 * * *\end{array}$ & $\begin{array}{c}(0.000) \\
0.030 * * *\end{array}$ & $\begin{array}{c}(0.000) \\
0.029 * * *\end{array}$ & $\begin{array}{c}(0.000) \\
0.029 * * *\end{array}$ \\
\hline & $(0.004)$ & $(0.004)$ & $(0.004)$ & $(0.004)$ & $(0.004)$ \\
\hline $\mathrm{M} / \mathrm{B}$ & -0.000 & $-0.001 * *$ & -0.001 & -0.000 & -0.000 \\
\hline & $(0.001)$ & $(0.000)$ & $(0.000)$ & $(0.000)$ & $(0.000)$ \\
\hline Tangibility & $-0.020 * * *$ & $-0.021 * * *$ & $-0.021 * * *$ & $-0.020 * * *$ & $-0.020 * * *$ \\
\hline & $(0.004)$ & $(0.004)$ & $(0.004)$ & $(0.004)$ & $(0.004)$ \\
\hline NWC/Assets & -0.006 & $-0.006^{*}$ & -0.005 & $-0.009^{* * *}$ & $-0.009 * * *$ \\
\hline & $(0.003)$ & $(0.003)$ & $(0.003)$ & $(0.003)$ & $(0.003)$ \\
\hline Capex/Assets & $0.108 * * *$ & $0.105 * * *$ & $0.107 * * *$ & $0.093 * * *$ & $0.093 * * *$ \\
\hline & $(0.017)$ & $(0.017)$ & $(0.017)$ & $(0.017)$ & $(0.016)$ \\
\hline R\&D/Sales & $-0.000 * * *$ & $-0.000 * *$ & $-0.000 * *$ & -0.000 & -0.000 \\
\hline & $(0.000)$ & $(0.000)$ & $(0.000)$ & $(0.000)$ & $(0.000)$ \\
\hline Div. Payer Dummy & $0.005 * * *$ & $0.005 * * *$ & $0.005 * * *$ & $0.004 * * *$ & $0.004 * * *$ \\
\hline & $(0.001)$ & $(0.001)$ & $(0.001)$ & $(0.001)$ & $(0.001)$ \\
\hline Industry Sigma & -0.020 & -0.020 & -0.025 & -0.021 & -0.021 \\
\hline & $(0.026)$ & $(0.027)$ & $(0.027)$ & $(0.026)$ & $(0.026)$ \\
\hline Beta KMV & 0.000 & 0.001 & 0.000 & 0.001 & 0.001 \\
\hline & $(0.000)$ & $(0.000)$ & $(0.000)$ & $(0.000)$ & $(0.000)$ \\
\hline Constant & $-0.014 * * *$ & $-0.009 *$ & $-0.009 * *$ & $-0.013 * * *$ & $-0.013 * * *$ \\
\hline & $(0.005)$ & $(0.005)$ & $(0.005)$ & $(0.005)$ & $(0.005)$ \\
\hline Observations & 10,219 & 10,219 & 10,219 & 10,219 & 10,219 \\
\hline R-squared & 0.047 & 0.046 & 0.047 & 0.053 & 0.053 \\
\hline
\end{tabular}


Table 5

Probability of a Liquidity Event

This table examines the probability of a drawdown in credit lines or a reduction in cash associated with a drop in profitability. In Panel A, we define liquidity events as follows: for credit line drawdowns, a liquidity event occurs if there is an increase in drawn revolving credit $(\Delta \mathrm{RC}>0)$ while profitability is negative; for cash, a liquidity event occurs if there is a reduction in cash $(\Delta$ Cash and ST Investments $<0)$ while profitability is negative. The probability of a liquidity event for credit lines is computed as the ratio of credit line liquidity events divided by the number of firmyears with a credit line. The probability of a liquidity event for cash is computed as the ratio of cash liquidity events divided by the number of firm years without a credit line. In Panel B, we compute the probability of profitability falling below $0 \%$ and $5 \%$, respectively for firms with and without a credit line. See Table A1 for variables description.

Panel A: Probability of a negative cash flow shock

\begin{tabular}{|c|c|c|c|c|c|c|}
\hline & $\begin{array}{c}\text { With } \\
\text { Credit Line }\end{array}$ & $\begin{array}{c}\text { W/out Credit } \\
\text { Line }\end{array}$ & t-stat & p-value & wilcoxon & p-value \\
\hline Probability of Profits $<0 \%$ & 0.094 & 0.423 & 53.078 & $(0.000)$ & 58.269 & $(0.000)$ \\
\hline Probability of Profits $<5 \%$ & 0.163 & 0.531 & 56.598 & $(0.000)$ & 58.037 & $(0.000)$ \\
\hline \multicolumn{7}{|c|}{ Panel B: Probability of a liquidity event } \\
\hline & Credit Line & Cash & t-stat & p-value & wilcoxon & $p$-value \\
\hline Probability of a Liquidity Event & $2.156 \%$ & $19.197 \%$ & 32.331 & $(0.000)$ & 40.969 & $(0.000)$ \\
\hline $\begin{array}{l}\text { Probability of a Liquidity Event }> \\
0.5 \% \text { of Assets }\end{array}$ & $2.062 \%$ & $18.523 \%$ & 31.679 & $(0.000)$ & 40.265 & $(0.000)$ \\
\hline
\end{tabular}


Table 6

Credit Line Usage across Top and Bottom Quintiles of Hedging Needs

This table provides summary statistics across groups of high versus low correlation of investment opportunities and cash-flow (low and high hedging needs, respectively). In Panel A, we examine the relationship between hedging needs and liquidity variables. Hedging needs are calculated at the 3-digit SIC code industry level as the correlation between firm-level cash flow and the mean industry annual investment activities (Hedging Investment Activities, item 311 + 46), and the median industry Tobin's Q (Hedging Tobin's Q). High hedging needs firms are those with a correlation in the bottom quintile, and low hedging needs are those with a correlation in the top quintile. In Panel B, we examine the relationship between hedging needs and the residuals computed from the regressions in Table 2 . In both panels we include a test for differences between samples with high and low hedging needs using the unequal variances t-test. For definitions of variables see the Table A1.

Panel A: Univariate relationship between hedging needs and liquidity variables

\begin{tabular}{|c|c|c|c|c|}
\hline & \multicolumn{4}{|c|}{ Variable: Mean (Median) } \\
\hline & $\begin{array}{l}\text { Presence of a Credit } \\
\text { Line (Dummy) }\end{array}$ & $\begin{array}{c}\text { Undrawn Credit / } \\
\text { Assets }\end{array}$ & $\begin{array}{c}\text { Undrawn } \\
\text { Ratio }\end{array}$ & $\begin{array}{c}\text { Revolving Credit } \\
\text { /Assets }\end{array}$ \\
\hline \multicolumn{5}{|l|}{ Industry median Invest. Activities } \\
\hline High hedging needs & 0.570 & 0.070 & 0.290 & 0.025 \\
\hline$N=4350$ & $(1.000)$ & $(0.026)$ & $(0.118)$ & $(0.000)$ \\
\hline Low hedging needs & 0.830 & 0.122 & 0.583 & 0.061 \\
\hline$N=4370$ & $(1.000)$ & $(0.099)$ & $(0.685)$ & $(0.005)$ \\
\hline t-test & 27.60 & 22.35 & 39.39 & 19.21 \\
\hline (p-value) & $(0.000)$ & $(0.000)$ & $(0.000)$ & $(0.000)$ \\
\hline \multicolumn{5}{|l|}{ Industry median Tobin's Q } \\
\hline High hedging needs & 0.731 & 0.096 & 0.431 & 0.032 \\
\hline$N=4061$ & $(1.000)$ & $(0.070)$ & $(0.431)$ & $(0.000)$ \\
\hline Low hedging needs & 0.816 & 0.121 & 0.557 & 0.063 \\
\hline$N=4346$ & $(1.000)$ & $(0.097)$ & $(0.656)$ & $(0.003)$ \\
\hline t-test & 9.30 & 10.08 & 16.11 & 14.99 \\
\hline (p-value) & $(0.000)$ & $(0.000)$ & $(0.000)$ & $(0.000)$ \\
\hline
\end{tabular}


Panel B: Relationship between hedging needs and the regression residuals from Table 2

\begin{tabular}{|c|c|c|c|c|}
\hline & \multicolumn{4}{|c|}{ Variable: Mean (Median) } \\
\hline & $\begin{array}{l}\text { Presence of a Credit } \\
\text { Line (Dummy) }\end{array}$ & $\begin{array}{c}\text { Undrawn Credit / } \\
\text { Assets }\end{array}$ & $\begin{array}{l}\text { Undrawn } \\
\text { Ratio }\end{array}$ & $\begin{array}{c}\text { Revolving Credit } \\
\text { /Assets }\end{array}$ \\
\hline \multicolumn{5}{|l|}{ Industry median Invest, Activities } \\
\hline High hedging needs & 0.069 & 0.000 & 0.024 & 0.004 \\
\hline$N=4350$ & $(0.356)$ & $(-0.023)$ & $(-0.016)$ & $(-0.004)$ \\
\hline Low hedging needs & 0.164 & 0.007 & 0.028 & 0.007 \\
\hline$N=4370$ & $(0.345)$ & $(-0.017)$ & $(0.087)$ & $(-0.016)$ \\
\hline$t$-test & 4.225 & 2.940 & 0.616 & 1.748 \\
\hline (p-value) & 0.000 & 0.003 & 0.538 & 0.080 \\
\hline \multicolumn{5}{|l|}{ Industry median Tobin's Q } \\
\hline High hedging needs & 0.146 & -0.001 & -0.002 & -0.005 \\
\hline$N=4061$ & $(0.416)$ & $(-0.024)$ & $(-0.008)$ & $(-0.016)$ \\
\hline Low hedging needs & 0.178 & 0.006 & 0.026 & 0.012 \\
\hline$N=4346$ & $(0.356)$ & $(-0.016)$ & $(0.084)$ & $(-0.014)$ \\
\hline$t$-test & 1.524 & 2.782 & 3.909 & 8.864 \\
\hline (p-value) & 0.128 & 0.005 & 0.000 & 0.000 \\
\hline
\end{tabular}


Table 7

Hedging Needs and the Use of Covenants

This table estimates the relationship between hedging needs and the use of covenants on credit lines using a Poisson specification. Hedging needs are calculated at the 3-digit SIC code industry level as the correlation between firm-level cash flow and the mean industry annual investment activities (Hedging Investment Activities, item $311+46$ ), and the median industry Tobin's Q (Hedging Tobin's Q). We obtain data on covenants from LPC Dealscan. We list all the covenants attached to credit lines for the firms in our sample during the period 2002-2008. In most cases, firms are granted several new credit line facilities in the same year. For these cases we report the median number of covenant across facilities. General Purpose LC is a dummy that takes value 1 if the stated purpose of the line of credit is "General Corporate Purposes", as reported in LPC Dealscan. When firms are granted several new credit line facilities in the same year we report the median value. All regressions include year fixed effects. Robust standard errors clustered at the firm level are reported in parentheses. ***,**, and * denote statistical significance at the $1 \%, 5 \%$, and $10 \%$ levels, respectively. See Table A1 for further descriptions of the variables.

\begin{tabular}{|c|c|c|c|c|c|c|c|c|}
\hline & (1) & (2) & (3) & (4) & (5) & (6) & (7) & (8) \\
\hline & $\begin{array}{r}\text { Cove } \\
\text { Drucker a }\end{array}$ & $\begin{array}{l}\text { Index } \\
\text { uri (2010) }\end{array}$ & $\begin{array}{r}\text { Cove } \\
\text { Demiroglu }\end{array}$ & $\begin{array}{l}\text { Index } \\
\text { ames (2010) }\end{array}$ & $\begin{array}{r}\text { Cove } \\
\text { Only C }\end{array}$ & $\begin{array}{l}\text { Index } \\
\text { venants }\end{array}$ & $\begin{array}{r}\text { Cove } \\
\text { Only }\end{array}$ & $\begin{array}{l}\text { Index } \\
\text { eeps }\end{array}$ \\
\hline Hedging Inv. Activities & $\begin{array}{c}-0.186^{* * *} \\
(0.055)\end{array}$ & & $\begin{array}{c}-0.126^{*} \\
(0.071)\end{array}$ & & $\begin{array}{c}-0.812 * * * \\
(0.113)\end{array}$ & & $\begin{array}{c}-0.526^{* * *} \\
(0.115)\end{array}$ & \\
\hline Hedging Tobin's Q & & $\begin{array}{l}-0.022 \\
(0.063)\end{array}$ & & $\begin{array}{c}0.107 \\
(0.082)\end{array}$ & & $\begin{array}{c}-0.789 * * * \\
(0.131)\end{array}$ & & $\begin{array}{c}-0.302 * * \\
(0.133)\end{array}$ \\
\hline Profitability & $\begin{array}{c}0.459 * * * \\
(0.090)\end{array}$ & $\begin{array}{c}0.438 * * * \\
(0.090)\end{array}$ & $\begin{array}{l}0.297 * * \\
(0.117)\end{array}$ & $\begin{array}{c}0.272 * * \\
(0.117)\end{array}$ & $\begin{array}{c}0.755 * * * \\
(0.187)\end{array}$ & $\begin{array}{c}0.723 * * * \\
(0.185)\end{array}$ & $\begin{array}{c}0.482 * * \\
(0.206)\end{array}$ & $\begin{array}{c}0.447 * * \\
(0.204)\end{array}$ \\
\hline Size & $\begin{array}{c}-0.189 * * * \\
(0.006)\end{array}$ & $\begin{array}{c}-0.191 * * * \\
(0.006)\end{array}$ & $\begin{array}{c}-0.176^{* * * *} \\
(0.008)\end{array}$ & $\begin{array}{c}-0.178 * * * \\
(0.008)\end{array}$ & $\begin{array}{c}-0.216 * * * \\
(0.012)\end{array}$ & $\begin{array}{c}-0.224 * * * \\
(0.012)\end{array}$ & $\begin{array}{c}-0.268 * * * \\
(0.012)\end{array}$ & $\begin{array}{c}-0.274 * * * \\
(0.012)\end{array}$ \\
\hline Book Leverage & $\begin{array}{c}0.611 * * * \\
(0.038)\end{array}$ & $\begin{array}{c}0.608 * * * \\
(0.038)\end{array}$ & $\begin{array}{c}0.651 * * * \\
(0.049)\end{array}$ & $\begin{array}{c}0.656^{* * *} \\
(0.049)\end{array}$ & $\begin{array}{c}0.834 * * * \\
(0.072)\end{array}$ & $\begin{array}{c}0.780 * * * \\
(0.072)\end{array}$ & $\begin{array}{c}1.422 * * * \\
(0.068)\end{array}$ & $\begin{array}{c}1.402 * * * \\
(0.068)\end{array}$ \\
\hline MB & $\begin{array}{c}-0.118^{* * *} \\
(0.010)\end{array}$ & $\begin{array}{c}-0.114 * * * \\
(0.010)\end{array}$ & $\begin{array}{c}-0.128 * * * \\
(0.013)\end{array}$ & $\begin{array}{c}-0.123 * * * \\
(0.013)\end{array}$ & $\begin{array}{c}-0.146 * * * \\
(0.020)\end{array}$ & $\begin{array}{c}-0.143 * * * \\
(0.020)\end{array}$ & $\begin{array}{c}-0.223 * * * \\
(0.023)\end{array}$ & $\begin{array}{c}-0.216^{* * * *} \\
(0.023)\end{array}$ \\
\hline Rated & $\begin{array}{c}0.029 \\
(0.021)\end{array}$ & $\begin{array}{c}0.029 \\
(0.021)\end{array}$ & $\begin{array}{c}0.015 \\
(0.027)\end{array}$ & $\begin{array}{c}0.014 \\
(0.027)\end{array}$ & $\begin{array}{l}-0.017 \\
(0.041)\end{array}$ & $\begin{array}{l}-0.004 \\
(0.041)\end{array}$ & $\begin{array}{c}0.208 * * * \\
(0.042)\end{array}$ & $\begin{array}{c}0.217 * * * \\
(0.042)\end{array}$ \\
\hline CF Volatility & $\begin{array}{l}-0.431 \\
(0.490)\end{array}$ & $\begin{array}{l}-0.422 \\
(0.491)\end{array}$ & $\begin{array}{c}0.366 \\
(0.632)\end{array}$ & $\begin{array}{c}0.361 \\
(0.633)\end{array}$ & $\begin{array}{c}-0.405 \\
(0.977)\end{array}$ & $\begin{array}{c}-0.293 \\
(0.983)\end{array}$ & $\begin{array}{l}-0.606 \\
(1.064)\end{array}$ & $\begin{array}{l}-0.655 \\
(1.069)\end{array}$ \\
\hline Current Ratio & $\begin{array}{c}0.008 \\
(0.019)\end{array}$ & $\begin{array}{c}0.007 \\
(0.019)\end{array}$ & $\begin{array}{c}0.028 \\
(0.025)\end{array}$ & $\begin{array}{c}0.029 \\
(0.025)\end{array}$ & $\begin{array}{l}-0.021 \\
(0.040)\end{array}$ & $\begin{array}{l}-0.033 \\
(0.040)\end{array}$ & $\begin{array}{c}0.013 \\
(0.040)\end{array}$ & $\begin{array}{c}0.011 \\
(0.039)\end{array}$ \\
\hline $\begin{array}{l}\text { Observations } \\
\text { Pseudo } \mathrm{R}^{2}\end{array}$ & $\begin{array}{l}4,499 \\
0.108\end{array}$ & $\begin{array}{l}4,515 \\
0.108\end{array}$ & $\begin{array}{c}4,499 \\
0.0952\end{array}$ & $\begin{array}{l}4,515 \\
0.0951\end{array}$ & $\begin{array}{c}4,499 \\
0.0878\end{array}$ & $\begin{array}{c}4,515 \\
0.0866\end{array}$ & $\begin{array}{l}4,499 \\
0.151\end{array}$ & $\begin{array}{l}4,515 \\
0.150\end{array}$ \\
\hline
\end{tabular}


Table 8

Hedging Needs and Covenant Violation

We estimate the relationship between the violation of a covenant and the hedging needs of firms, using a Probit estimation. The dependent variable is a dummy for the presence of at least one covenant violation during that year. Hedging needs are calculated at the 3-digit SIC code industry level as the correlation between firm-level cash flow and the mean industry annual investment activities (Hedging Investment Activities, item $311+46$ ), and the median industry Tobin's Q (Hedging Tobin's Q). The sample consists of non-utilities (excluding SIC codes 4900-4949) and non-financials (excluding SIC codes 6000-6999) U.S. firms covered by Capital IQ, Compustat and LPC DealScan that have information on covenant violations (online data obtained from Sufi's website (Nini, Smith, Sufi (2010)) over the period 2002 to 2008. The variable Covenant Index is calculated as in Drucker and Puri (2010). Robust standard errors clustered at the firm level are reported in parentheses. $* * *, * *$, and $*$ denote statistical significance at the $1 \%, 5 \%$, and $10 \%$ levels, respectively. See Table A1 for further descriptions of the variables.

\begin{tabular}{|c|c|c|c|c|}
\hline & (1) & (2) & (3) & (4) \\
\hline & \multicolumn{4}{|c|}{ Covenant Violation (Dummy) } \\
\hline Hedging Inv. Activities & $\begin{array}{c}-0.464 * * * \\
(0.173)\end{array}$ & $\begin{array}{c}-0.477 * * * \\
(0.182)\end{array}$ & & \\
\hline Hedging Tobin's Q & & & $\begin{array}{l}-0.381^{*} \\
(0.201)\end{array}$ & $\begin{array}{l}-0.380^{*} \\
(0.213)\end{array}$ \\
\hline Covenant Index & $\begin{array}{c}0.047 * * * \\
(0.008)\end{array}$ & $\begin{array}{c}0.018 * * \\
(0.009)\end{array}$ & $\begin{array}{c}0.047 * * * \\
(0.008)\end{array}$ & $\begin{array}{c}0.019 * * \\
(0.009)\end{array}$ \\
\hline Profitability & $\begin{array}{c}-3.409^{* * *} \\
(0.262)\end{array}$ & $\begin{array}{c}-2.562 * * * \\
(0.279)\end{array}$ & $\begin{array}{c}-3.457 * * * \\
(0.262)\end{array}$ & $\begin{array}{c}-2.609 * * * \\
(0.278)\end{array}$ \\
\hline Size & & $\begin{array}{c}-0.182 * * * \\
(0.024)\end{array}$ & & $\begin{array}{c}-0.183 * * * \\
(0.024)\end{array}$ \\
\hline Book Leverage & & $\begin{array}{c}0.669^{* * *} \\
(0.135)\end{array}$ & & $\begin{array}{c}0.635^{* * * *} \\
(0.135)\end{array}$ \\
\hline MB & & $\begin{array}{c}-0.182 * * * \\
(0.033)\end{array}$ & & $\begin{array}{c}-0.179 * * * \\
(0.033)\end{array}$ \\
\hline CF Volatility & & $\begin{array}{l}0.001^{*} \\
(0.000)\end{array}$ & & $\begin{array}{l}0.001 * \\
(0.000)\end{array}$ \\
\hline Rated & & $\begin{array}{c}-0.173 * * \\
(0.077)\end{array}$ & & $\begin{array}{c}-0.171^{* *} \\
(0.077)\end{array}$ \\
\hline Constant & $\begin{array}{c}-0.929 * * * \\
(0.049)\end{array}$ & $\begin{array}{c}0.404 * * * \\
(0.156)\end{array}$ & $\begin{array}{c}-0.903 * * * \\
(0.052)\end{array}$ & $\begin{array}{c}0.441 * * * \\
(0.157)\end{array}$ \\
\hline Observations & 4,367 & 4,273 & 4,384 & 4,289 \\
\hline
\end{tabular}


Figure 1 Timeline of Model

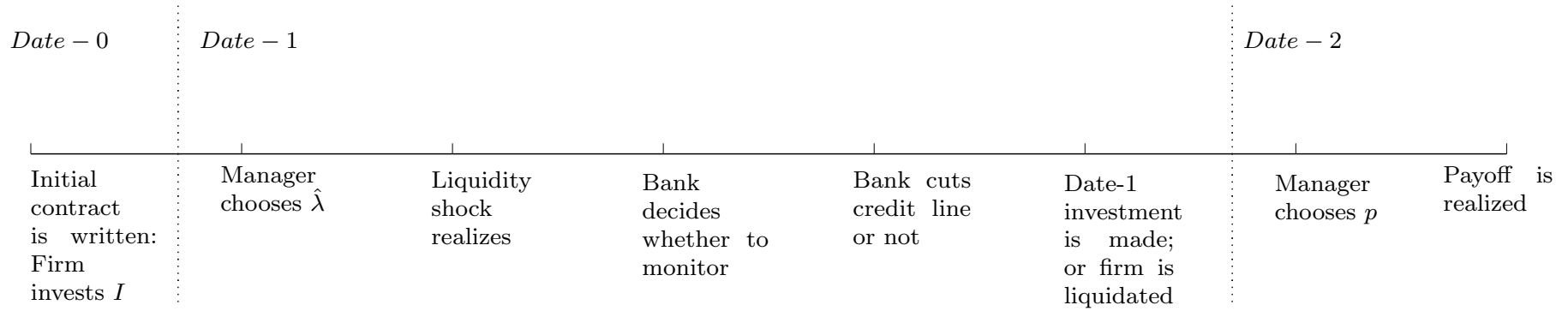


Figure 2 Bank's decision tree and payoffs

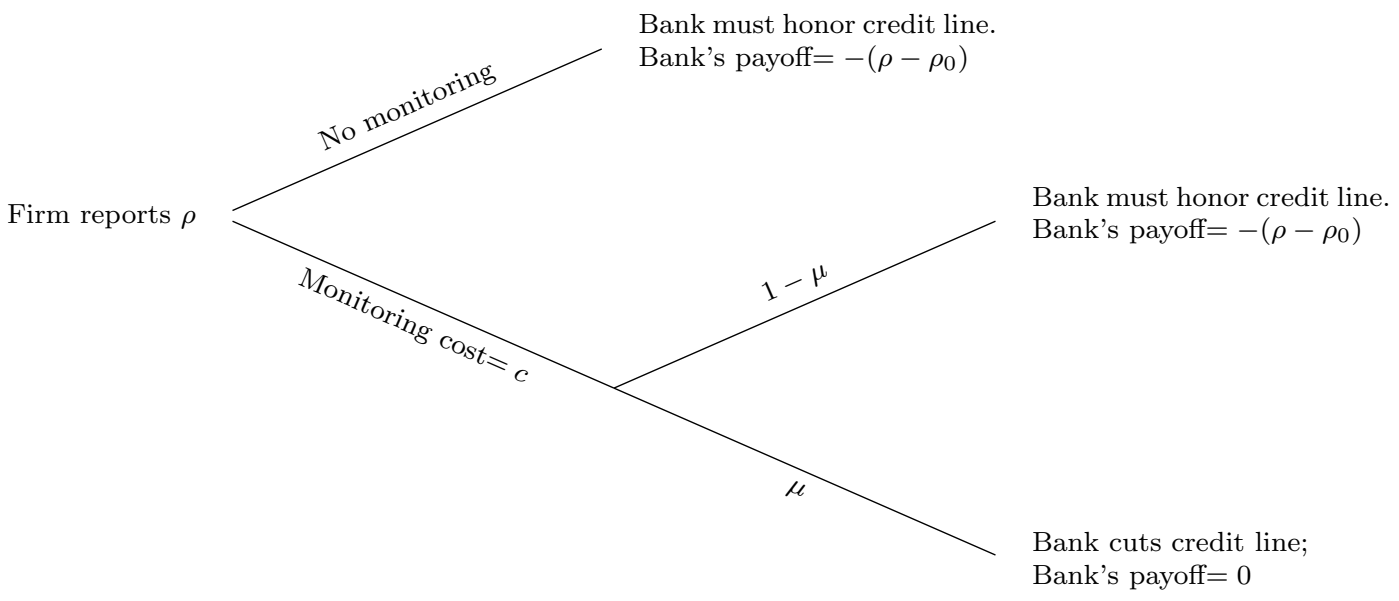


Figure 3 Firm's choice of $\lambda$ and payoffs

Figure 3a Liquid Project: $\hat{\lambda}=\lambda$

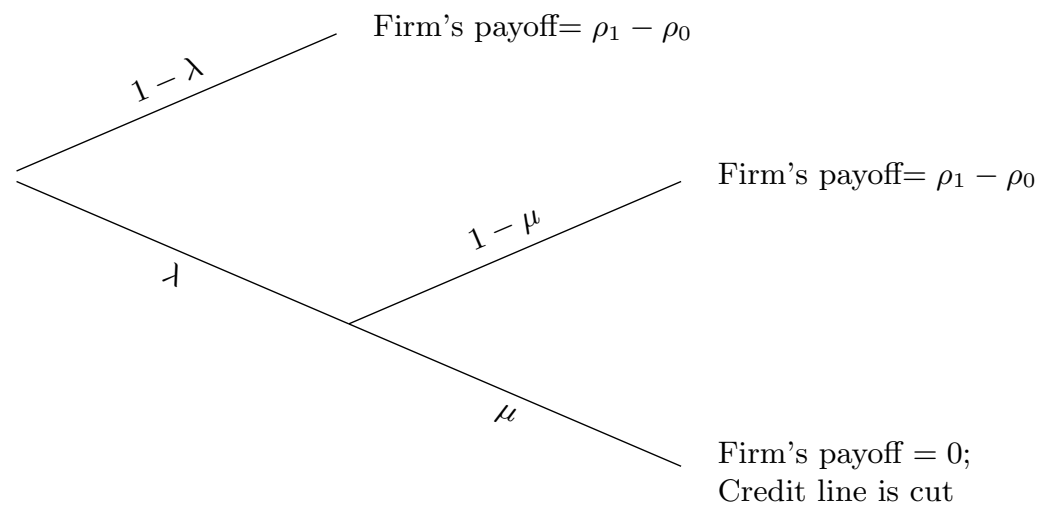

Figure 3b Illiquid Project: $\hat{\lambda}=\lambda^{\prime}$

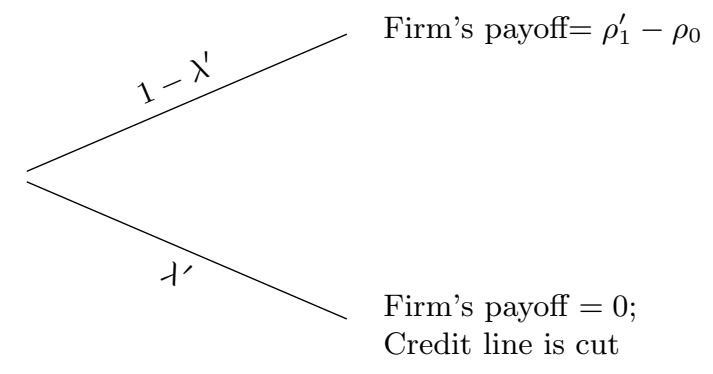


Figure 4 Liquidity management for good times

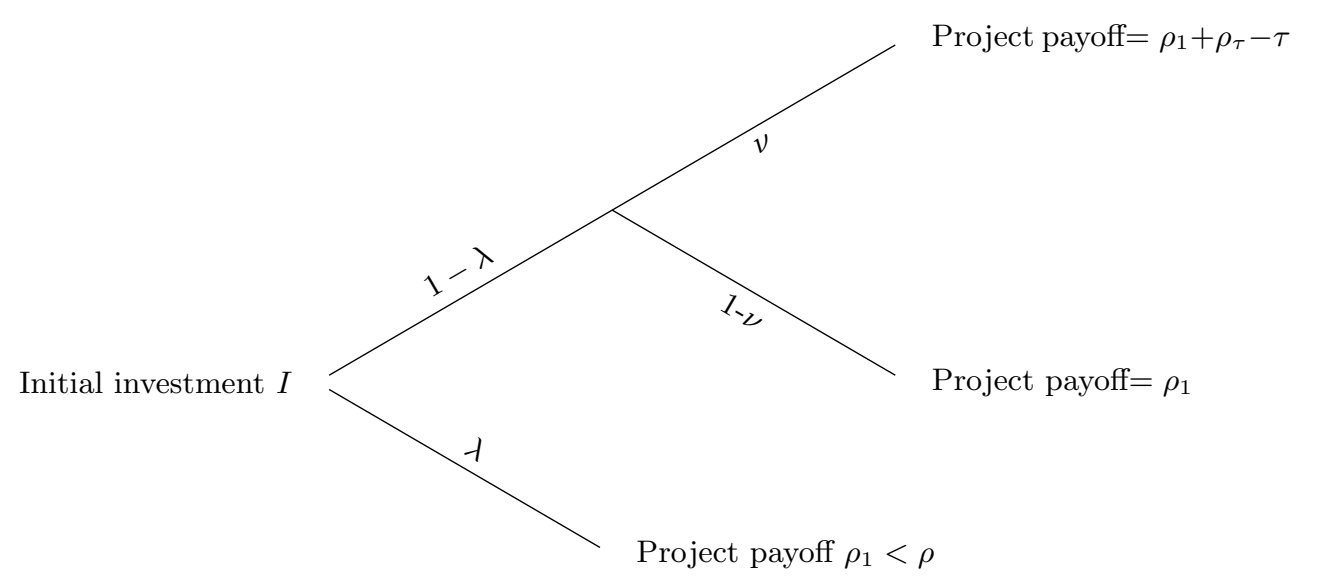




\section{Figure 5}

Distribution of Liquidity Shocks

This figure presents evidence on the differences in the distribution of profitability between firms with a credit line ("LC Firms") and firms without one ("Cash Firms"). The probability density displayed is an estimate using the data in the sample based on a normal kernel function and evaluated at 100 equally spaced points that cover the range of the data.

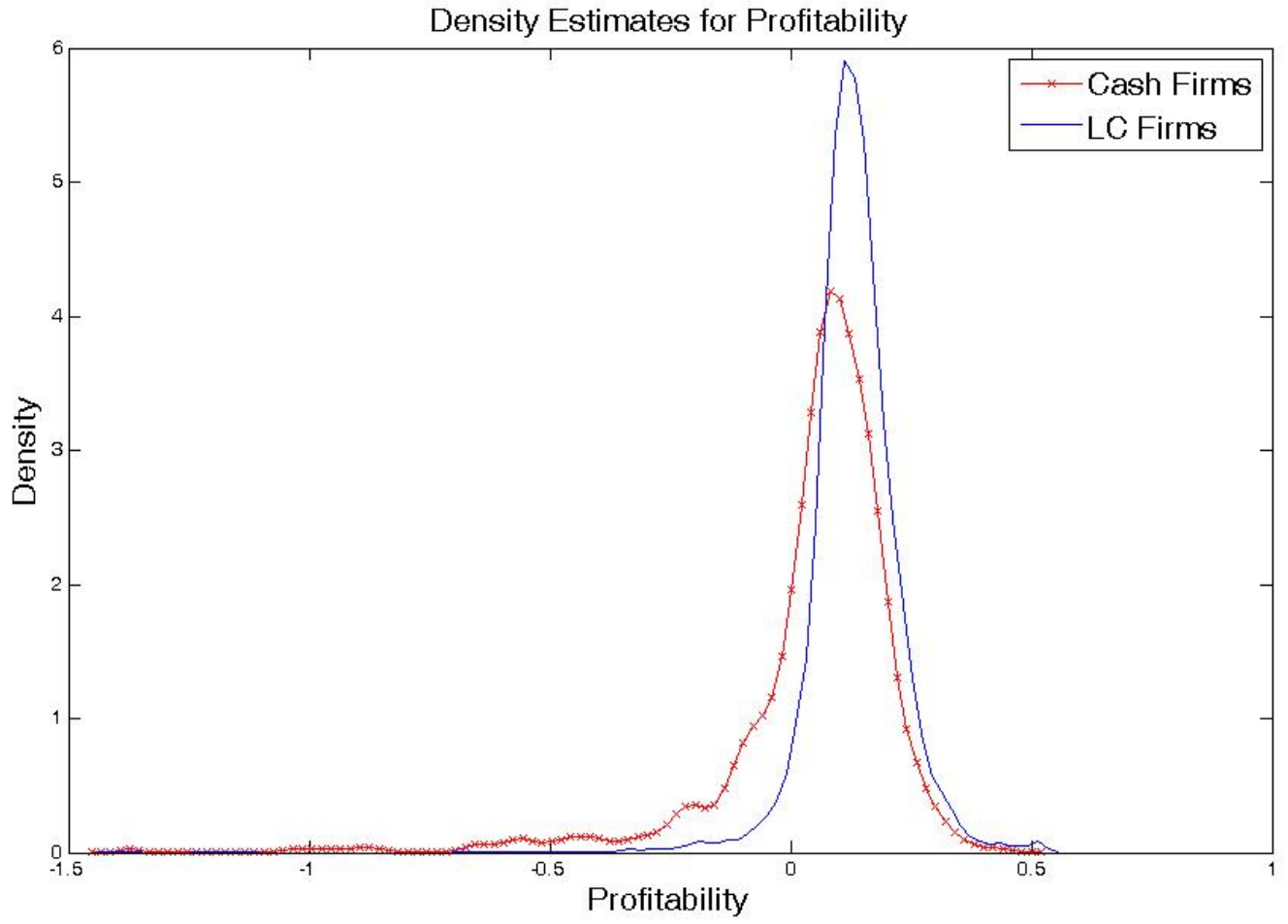


Figure 6

Presence of a Credit Line and Rating

This figure presents evidence on the differences in credit ratings between firms with a credit line ("LC Firms") and firms without one ("Cash Firms"). Credit ratings are aggregated into 8 groups: AAA, AA, A, BBB, BB, B, D to $\mathrm{CCC}+$, and unrated. Each bar represents the percentage of firms in each group with a particular rating.

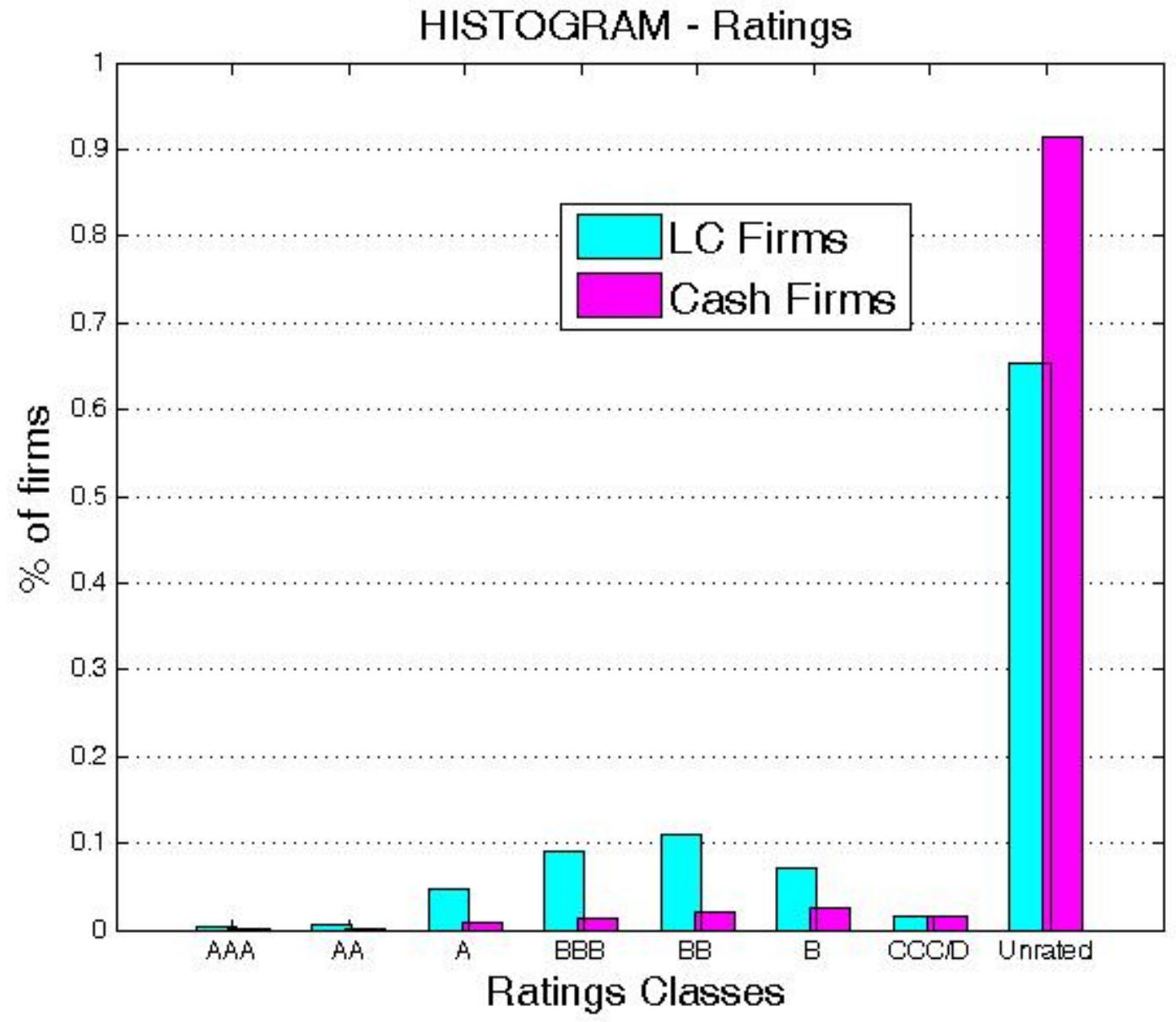


Table A1.

Description of Variables

\begin{tabular}{ll}
\hline Variable & Construction \\
\hline Beta KMV & $\begin{array}{l}\text { Firm's asset (unlevered) beta, calculated from equity (levered) betas and a Merton-KMV } \\
\text { formula as in Acharya, Almeida and Campello (2010) }\end{array}$ \\
Book Leverage & Total Debt / Total Assets (6) \\
BV Equity & $\begin{array}{l}\text { Total Assets (6) - Total Liabilities (181) - Deferred Taxes and Investment Tax Credit (35) - } \\
\text { Preferred Stock }\end{array}$ \\
Cash/Assets & Cash and Short-Term Investments (1) divided by Assets (item 6). \\
CF Volatility & $\begin{array}{l}\text { Standard Deviation of Operating Income (13) over Previous 12 Quarters Scaled by Total } \\
\text { Assets (6) }\end{array}$ \\
$\begin{array}{l}\text { Covenant Index } \\
\text { (Demiroglu and } \\
\text { James (2010)) }\end{array}$ & $\begin{array}{l}\text { Covenants, Asset Sales Sweep, Equity Issuance Sweep, Debt Issuance Sweep. } \\
\text { Where Dummy Financial Covenants equals one is at least two of the following covenants are } \\
\text { included: Debt/Tangible Assets, Max Capex, Max Debt/Assets, Max Debt/Ebitda, Max } \\
\text { Debt/Equity, Max Leverage, Max Senior Debt/Ebitda, Max Senior Leverage, Min Change } \\
\text { Interest Coverage, Min Current Ratio, Min Debt Coverage, Min Ebitda, Min Equity/Asset, Min } \\
\text { Fixed Charge, Min Interest Coverage, Min Net Worth/Assets, Min Quick Ratio, Net Worth, } \\
\text { Other Ratio, Other, Tangible Net Worth. }\end{array}$
\end{tabular}

Covenant Index

Sum of following covenants: \% Of Excess CF, \% Of Net Income, Asset Sales Sweep, (Drucker and Puri Collateral Release, Debt Issuance Sweep, Dividend Restrictions, Equity Issuance Sweep, (2010)

Excess CF Sweep, Insurance Proceeds Sweep, Max Capex, Max Debt/Assets, Max Debt/Ebitda, Max Debt/Equity, Max Debt/Tangible Assets, Max Leverage, Max Senior Debt/Ebitda, Max Senior Leverage, Min Change Interest Coverage, Min Current Ratio, Min Debt Coverage, Min Ebitda, Min Equity/Asset, Min Fixed Charge, Min Interest Coverage, Min Net Worth/Assets, Min Quick Ratio, Net Worth, Other, Other Ratio, Tangible Net Worth.

Covenant Index (Only CF Covenants) Sum of following covenants: \% Of Excess CF, \% Of Net Income, Excess CF Sweep, Max Capex, Max Debt/Ebitda, Max Senior Debt/Ebitda, Min Change Interest Coverage, Min Ebitda.

Covenant Index (Only Sweeps)

Sum of following covenants: Asset Sales Sweep, Debt Issuance Sweep, Equity Issuance Sweep, Excess CF Sweep, Insurance Proceeds Sweep.

Dividend Payer

A dummy variable that takes the value of one if common stock dividends (21) are positive, and zero otherwise

Hedging based on investment Activities

Correlation between three-digit median industry investment activities adjusted for R\&D expenses (item $311+46$ ) and the firm-year cash flows measured as in Acharya, Almeida and Campello (2007). The three-digit median industry investment activities is computed on the sample of unconstrained firms, defined as firms that pay dividends, have assets above $\$ 500 \mathrm{~m}$ and rating above $\mathrm{B}+$.

Hedging based on Tobin's Q

Correlation between three-digit median industry market-to-book and the firm-year cash flows measured as in Acharya, Almeida and Campello (2007). The three-digit median industry market-to-book is computed on the sample of unconstrained firms, defined as firms that pay dividends, have assets above $\$ 500 \mathrm{~m}$ and rating above $\mathrm{B}+$.

Investing Activities - Increase in Investments (113) + Sale of Investments (109) + Change in Short Term Net Cash Flow Investments (309) - Capital Expenditures (128) + Sale of Property, Plant, and Equipment (107) 
- Acquisitions (129) + Investment Activities Other (310)

$\mathrm{M} / \mathrm{B}$

(Market Value of Equity + Total Debt + Preferred Stock Liquidating Value (10) - Deferred Taxes and Investment Tax Credit (35)) / Total Assets (6)

Market Value of Equity

Preferred Stock

Profitability

Rated

Rating

Size

Tangibility

Total Debt
Stock Price $(199) \times$ Common Shares Used to Calculate EPS (54)

Max[Preferred Stock Liquidating Value (10), Preferred Stock Redemption Value (56), Preferred Stock Carrying Value (130)]

Operating Income Before Depreciation (13) / Total Assets (6)

A dummy variable that takes the value of one if the firm is rated by the S\&P, and zero otherwise

Monthly S\&P ratings (280). Takes 23 values: 1 = "AAA", $2=" \mathrm{AA}+", 3=" \mathrm{AA} ", 4=" \mathrm{AA}-"$, 5="A+", 6="A", 7="A-", 8="BBB+", 9="BBB", 10="BBB-", 11="BB+", 12="BB", 13="BB-", 14="B+", 15="B", 16="B-", 17="CCC+", 18="CCC", 19="CCC-", 20="CC", 21="SD", 22="D", $23=$ Unrated

Logarithm of Revenues (12)

Net Property, Plant, and Equipment (8) / Total Assets (6)

Debt in Current Liabilities (34) + Long-Term Debt (9) 
Table A2: Robustness Check on the Relationship between Profitability and Drawdowns This table presents a robustness check for the regression results of Table 4 relating to the relationship between profitability and drawdowns of credit lines. The dependent variable is the annual draw down in credit lines: the variable takes value zero if the change in drawn credit lines is non-positive. Profits $>0 \%$ and Profits $>5 \%$ are dummies for profitability being respectively above $0 \%$ and $5 \%$. All columns employ a Tobit specification with 8739 left-censored observations at Drawdown $\leq 0$. Year and Rating fixed effects included. Rating fixed effects are based on 22 rating dummies and the unrated dummy. Robust standard errors clustered at the firm level are reported in parentheses. See Table A1 for further descriptions of the variables. ${ }^{* *},{ }^{* *}$, and $*$ denote statistical significance at the $1 \%, 5 \%$, and $10 \%$ levels, respectively.

\begin{tabular}{|c|c|c|c|c|c|}
\hline & (1) & (2) & (3) & (4) & (5) \\
\hline & \multicolumn{5}{|c|}{ Drawdowns in Revolving Credit } \\
\hline Profitability & $\begin{array}{c}-0.054 * * * \\
(0.002)\end{array}$ & & & & \\
\hline Profits $>0 \%$ & & $\begin{array}{c}-0.015 * * * \\
(0.001)\end{array}$ & & & \\
\hline Profits $>5 \%$ & & & $\begin{array}{c}-0.012 * * * \\
(0.001)\end{array}$ & & \\
\hline Change in Profitability & & & & $\begin{array}{c}-0.098 * * * \\
(0.001)\end{array}$ & \\
\hline Increases in Profitability & & & & & $\begin{array}{c}-0.117 * * * \\
(0.005)\end{array}$ \\
\hline Decreases in Profitability & & & & & $\begin{array}{c}-0.087 * * * \\
(0.003)\end{array}$ \\
\hline Size & $\begin{array}{c}-0.002^{* * *} \\
(0.000)\end{array}$ & $\begin{array}{c}-0.002 * * * \\
(0.000)\end{array}$ & $\begin{array}{c}-0.003 * * * \\
(0.000)\end{array}$ & $\begin{array}{c}-0.003^{* * *} \\
(0.000)\end{array}$ & $\begin{array}{c}-0.003^{* * *} \\
(0.000)\end{array}$ \\
\hline Book Leverage & $\begin{array}{c}0.129 * * * \\
(0.002)\end{array}$ & $\begin{array}{c}0.131^{* * *} \\
(0.002)\end{array}$ & $\begin{array}{c}0.132 * * * \\
(0.002)\end{array}$ & $\begin{array}{c}0.129 * * * \\
(0.002)\end{array}$ & $\begin{array}{c}0.129 * * * \\
(0.002)\end{array}$ \\
\hline $\mathrm{M} / \mathrm{B}$ & $\begin{array}{c}-0.009^{* * *} \\
(0.000)\end{array}$ & $\begin{array}{c}-0.009^{* * *} \\
(0.000)\end{array}$ & $\begin{array}{c}-0.009^{* * *} \\
(0.000)\end{array}$ & $\begin{array}{c}-0.009^{* * *} \\
(0.000)\end{array}$ & $\begin{array}{c}-0.009^{* * *} \\
(0.000)\end{array}$ \\
\hline Tangibility & $\begin{array}{c}-0.005^{* * *} \\
(0.002)\end{array}$ & $\begin{array}{c}-0.007^{* * * *} \\
(0.002)\end{array}$ & $\begin{array}{c}-0.007 * * * \\
(0.002)\end{array}$ & $\begin{array}{c}-0.005^{* * *} \\
(0.002)\end{array}$ & $\begin{array}{c}-0.005^{* * *} \\
(0.002)\end{array}$ \\
\hline NWC/Assets & $\begin{array}{c}0.035^{* * *} \\
(0.001)\end{array}$ & $\begin{array}{c}0.032^{* * *} \\
(0.001)\end{array}$ & $\begin{array}{c}0.033^{* * *} \\
(0.001)\end{array}$ & $\begin{array}{c}0.029 * * * \\
(0.001)\end{array}$ & $\begin{array}{c}0.028^{* * *} \\
(0.001)\end{array}$ \\
\hline Capex/Assets & $\begin{array}{c}0.218^{* * *} \\
(0.005)\end{array}$ & $\begin{array}{c}0.212 * * * \\
(0.005)\end{array}$ & $\begin{array}{c}0.216^{* * *} \\
(0.005)\end{array}$ & $\begin{array}{c}0.192 * * * \\
(0.005)\end{array}$ & $\begin{array}{c}0.194 * * * \\
(0.005)\end{array}$ \\
\hline R\&D/Sales & $\begin{array}{c}-0.002 * * * \\
(0.000)\end{array}$ & $\begin{array}{c}-0.001 * * * \\
(0.000)\end{array}$ & $\begin{array}{c}-0.001 * * * \\
(0.000)\end{array}$ & $\begin{array}{c}-0.001 * * * \\
(0.000)\end{array}$ & $\begin{array}{c}-0.001^{* * *} \\
(0.000)\end{array}$ \\
\hline Div. Payer Dummy & $\begin{array}{c}0.005 * * * \\
(0.001)\end{array}$ & $\begin{array}{c}0.004 * * * \\
(0.001)\end{array}$ & $\begin{array}{c}0.004 * * * \\
(0.001)\end{array}$ & $\begin{array}{c}0.003^{* * *} \\
(0.001)\end{array}$ & $\begin{array}{c}0.003^{* * *} \\
(0.001)\end{array}$ \\
\hline Industry Sigma & $\begin{array}{c}-0.217 * * * \\
(0.025)\end{array}$ & $\begin{array}{c}-0.216^{* * *} \\
(0.025)\end{array}$ & $\begin{array}{c}-0.226^{* * * *} \\
(0.025)\end{array}$ & $\begin{array}{c}-0.207 * * * \\
(0.024)\end{array}$ & $\begin{array}{r}-0.206^{* * * *} \\
(0.025)\end{array}$ \\
\hline $\begin{array}{l}\text { Observations } \\
\text { R-squared }\end{array}$ & 12,061 & 12,063 & 12,063 & 12,055 & 12,055 \\
\hline
\end{tabular}

